OPEN ACCESS

Edited by:

Zhuolun $\mathrm{Li}$

Lanzhou University, China

Reviewed by:

Johanna Lomax,

University of Giessen, Germany Jeff Pigati,

United States Geological Survey (USGS), United States

${ }^{*}$ Correspondence: Steffen Mischke smi@hi.is

Specialty section:

This article was submitted to Quaternary Science, Geomorphology and Paleoenvironment

a section of the journal

Frontiers in Earth Science

Received: 08 June 2021

Accepted: 19 August 2021 Published: 03 September 2021

Citation:

Mischke S, Lai Z, Faershtein G, Porat N, Röhl M, Braun P, Kalbe J and Ginat $H$ (2021) A Late Pleistocene Wetland Setting in the Arid Jurf ed Darawish Region in Central Jordan.

Front. Earth Sci. 9:722435.

doi: 10.3389/feart.2021.722435

\section{A Late Pleistocene Wetland Setting in the Arid Jurf ed Darawish Region in Central Jordan}

\author{
Steffen Mischke ${ }^{1 *}$, Zhongping Lai ${ }^{2}$, Galina Faershtein ${ }^{3}$, Naomi Porat ${ }^{4}$, Matthias Röhl ${ }^{5}$, \\ Paul Braun ${ }^{6}$, Johannes Kalbe ${ }^{7}$ and Hanan Ginat ${ }^{8}$ \\ ${ }^{1}$ Institute of Earth Sciences, University of Iceland, Reykjavik, Iceland, ${ }^{2}$ Institute of Marine Sciences, Shantou University, Shantou, \\ China, ${ }^{3}$ Weizmann Institute of Science, Rehovot, Israel, ${ }^{4}$ The Geological Survey of Israel, Jerusalem, Israel, ${ }^{5}$ Institute of Geological \\ Sciences, Free University of Berlin, Berlin, Germany, ${ }^{6}$ Musée National d'Histoire Naturelle, Luxembourg, Luxembourg, ${ }^{7}$ Faculty of \\ Agricultural and Environmental Sciences, University of Rostock, Rostock, Germany, ${ }^{8}$ Dead Sea and Arava Science Center, \\ Jerusalem, Israel
}

Current conditions in the southern Levant are hyperarid, and local communities rely on fossil subsurface water resources. The timing of more favourable wetter periods and also their spatial characteristics are not yet well constrained. To improve our understanding of past climate and environmental conditions in the deserts of the southern Levant, sedimentary sections including artefact-bearing beds from Jurf ed Darawish on the Central Jordanian Plateau were investigated using sedimentological and micropalaeontological analyses and OSL dating. Grain-size analysis and structures of the clayey-silty sediments show that they mainly represent reworked loess deposits. The OSL ages suggest that these fine-grained sediments were accumulated during Marine Isotope Stages (MIS) 5-3. Recorded ostracod valves (mostly Potamocypris, llyocypris and Pseudocandona), remains of aquatic and terrestrial gastropod shells, and charophyte gyrogonites and stem encrustations indicate that an in-stream wetland existed at the location of Jurf ed Darawish during MIS 5-4 which was replaced by a vegetated alluvial plain in MIS 3. The prevailing aggradational setting was replaced by an erosional setting sometime after $30 \mathrm{ka}$. Abundant artefacts, distributed over a vertical range of up to $40 \mathrm{~cm}$ in a bed covered by a sedimentary sequence of $12-\mathrm{m}$ thickness, provide evidence for the presence of humans in the region during a relatively long period from ca. 85 to $65 \mathrm{ka}$. The reconstruction of an in-stream wetland at Jurf ed Darawish, and the presence of humans at the site and in other desert regions of the Jordanian Plateau, the Wadi Arava/Araba, and the Negev and the Nefud deserts, show that the regional climate in the late MIS 5 and MIS 4 was significantly wetter than today and provided favourable conditions for humans in the Southern Levant and the northwestern Arabian Peninsula.

Keywords: Southern Levant, OSL dating, granulometry analysis, Ostracoda (Crustacea), human migration

\section{HIGHLIGHTS}

- aggradational setting from $>100$ to at least $30 \mathrm{ka}$

- transition from aggradation to incision sometime afterwards

- in-stream wetland during MIS 5 and 4

- vegetated alluvial plain in MIS 3

- presence of humans during ca. 85 to $65 \mathrm{ka}$ 


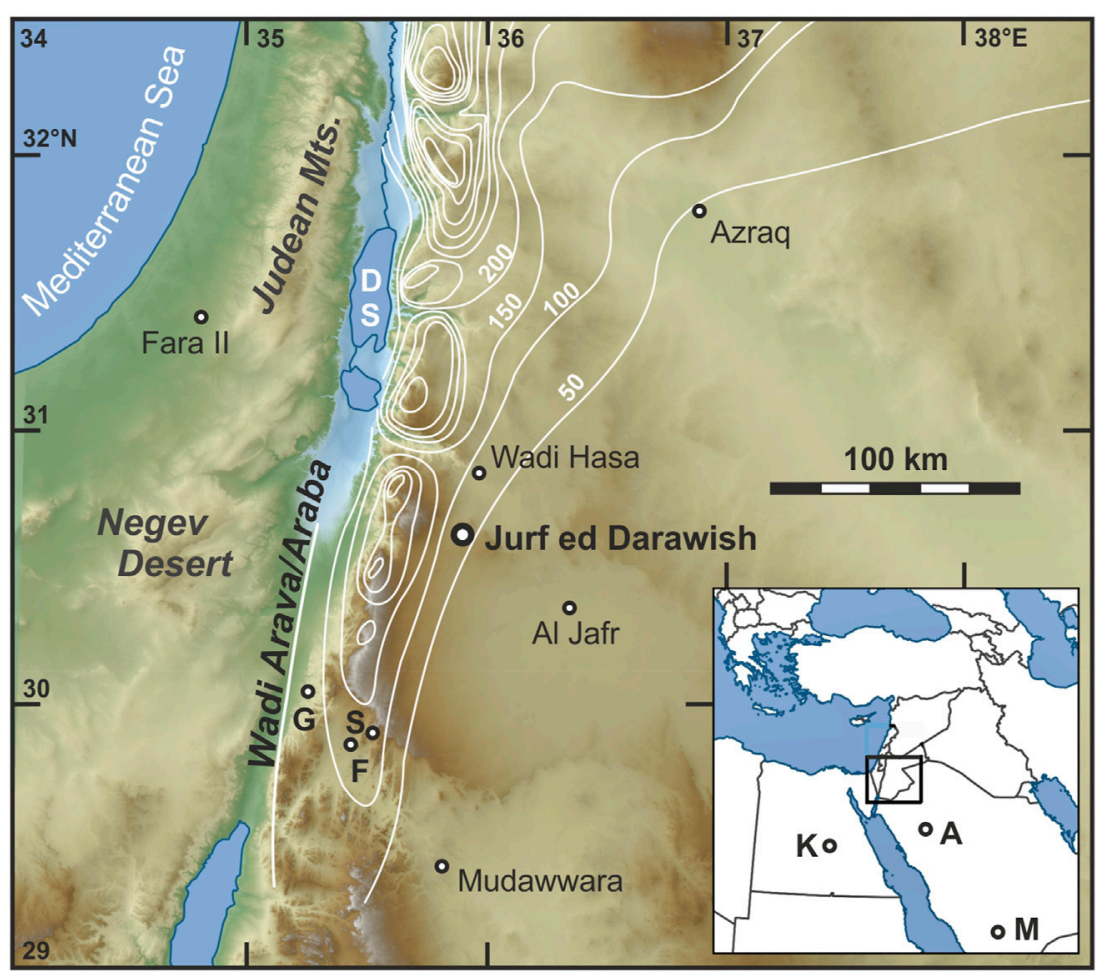

FIGURE 1 | Location of Jurf ed Darawish in the southern Levant and those of other study sites mentioned in the text (DS Dead Sea, A Al Wusta and Alathar, F Tor Faraj, G Gharandal, K Kharga and Kurkur oases, M Mundafan, S Tor Sabiha). Isohyets from Suleiman and Al-Bakri (2011). The colours refer to elevation. Map base prepared by Joe Roe (https://commons.wikimedia.org/wiki/User:Joe_Roe).

\section{INTRODUCTION}

The dispersal of anatomically modern humans out of Africa in the Pleistocene was one of the major steps in hominin evolution, but migration timings and the potential role of climate which possibly enabled occupation of previously uninhabited regions, and related landscape changes and available dispersal pathways, are still controversial (Vaks et al., 2007; Garcea, 2012; Groucutt et al., 2018). The region of the southern Levant and the Arabian Peninsula plays a key role in the debate due to its generally arid climate and its crucial geographical position as a barrier or bridge between the wetter regions of northern and eastern Africa on the one side and those of eastern Europe and western Asia on the other (Vaks et al., 2007; Waldmann et al., 2010). Wetter or "pluvial" periods in the southern Levant and the Arabian Peninsula may have provided favourable conditions for human dispersal, and some researchers argue that such conditions typically prevailed during the interglacials when monsoonal circulation was intensified in comparison to the drier glacials (Fleitmann et al., 2003; Groucutt et al., 2018; Stewart et al., 2020a). In contrast, other researchers regard the glacials as the favourable periods when lowered temperature and evaporation possibly caused a higher moisture availability and contraction of desert regions (Vaks et al., 2003; Waldmann et al., 2010).

The increasing number of geological and archaeological studies in northern Africa, the southern Levant and Arabian Peninsula allow the identification of temporal and spatial patterns. Garcea (2012) suggested two distinct periods of human dispersal out-of-
Africa, between ca. 130 to 80 and after $50 \mathrm{ka}$. The time span in between is described as a period of climate deterioration when hyperaridity was established in the Sahara and southern Levant (Shea, 2003; Garcea, 2012). However, this period includes the initiation of the Dead Sea's precursor, Lake Lisan, whose level rose dramatically by $70-80 \mathrm{~m}$, a phase of speleothem growth in the rain-shadow of the Judean Mountains and also of travertine formation in the Western Desert in Egypt (Crombie et al., 1997; Vaks et al., 2003; Waldmann et al., 2007).

In contrast to today's unique characteristic of the Dead Sea as the only major lake of the southern Levant and Arabian Peninsula, additional Quaternary lakes were reconstructed in the region based on analyses of sediments, fossils and shoreline features (Schuldenrein and Clark, 1994; Moumani et al., 2003; Schuldenrein and Clark, 2003; Davies, 2005; Petit-Maire et al., 2010; Rosenberg et al., 2012; Groucutt et al., 2015; Ginat et al., 2018). Inferred surface water bodies must have resulted from significant changes in precipitation or moisture availability (Schuldenrein and Clark, 1994; Davies, 2005; Petit-Maire et al., 2010). Periods of Pleistocene lake formation are disputed for some of these locations (e.g., Mudawwara), whilst some of the earlier inferences of palaeo-lakes were revised as palaeo-wetlands following more recent investigations of previously studied locations (Petit-Maire et al., 2010; Catlett et al., 2013; Winer, 2010; Mischke et al., 2015; Figure 1). Most reports of Holocene lakes on the Arabian Peninsula were challenged in a recent reassessment of the available evidence by Enzel et al. (2015). 




FIGURE 2 | (A) Exposed sediment Section 3 and Section 9. The white line marks the position and lateral distribution of artefacts on the SE-facing slope of the main wadi. The white cross marks the position of one additional artefact in Section 9. South-dipping Maastrichtian limestone beds in foreground. Two persons for scale (white arrow). (B) Section 3 and Section 9 at wadi slopes (partly marked by dotted lines). White line shows the position of artefacts as in A. The stylized eye shows the view direction of $A$, and the inset illustrates the main and tributary wadis.

Thus, thorough multi-proxy studies are required to reconstruct Quaternary landscape change in the region. In addition, robust chronologies are a prerequisite to discuss periods of human presence and potential controls of climate.

We conducted a sedimentological and dating study at Jurf ed Darawish on the Jordanian Plateau where an initial investigation by Moumani et al. (2003) had reported Palaeolithic artefacts embedded in exposed Late Pleistocene lacustrine sediments (Figure 1). Our work had the aim to improve knowledge 1) when sediments accumulated at Jurf ed Darawish, 2) when humans were present in the region, and 3) to reassess the inferred depositional setting of a lake proposed by Moumani et al. (2003).

\section{STUDY AREA}

The investigated sediment sections are located on the central Jordanian Plateau in the southern vicinity of the village Jurf ed
Darawish at ca. $30.687^{\circ} \mathrm{N}$ and $35.858^{\circ} \mathrm{E}$, at an altitude of ca. $940 \mathrm{~m}$ above sea level (asl; Figures 1, 2). Unconsolidated Quaternary alluvial sediments are widely distributed in the region, capping the Upper Cretaceous (Maastrichtian) marine limestone bedrock which is exposed on the floors of incised wadis and on hill slopes to the east (Moumani, 1996; Figure 2). Eocene limestone is exposed in the southeast of Jurf ed Darawish. In addition, Neogene basalt flows occur within a distance of a few kilometres to the north, west and south (Moumani et al., 2003). There are no natural surface waters near Jurf ed Darawish. However, Wadi El Jurf at the investigated sections is connected to Wadi Juheira, located in the southwest at ca. 1,000 $\mathrm{m}$ asl upstream, and to Wadi Al Hasa at ca. $800 \mathrm{~m}$ asl in the northeast downstream. Thus, surface runoff following rare rain events in the region is directed to Wadi Al Hasa, and may eventually reach the Dead Sea (Figure 1).

Mean January, mean July and mean annual temperatures at Ma'an, $60 \mathrm{~km}$ further south, are $7.5,25.4$ and $17.3^{\circ} \mathrm{C}$, respectively 
(www.worldclimate.com). Mean annual precipitation is $41.2 \mathrm{~mm}$ with precipitation mostly occurring during the winter season. Potential evaporation exceeds $3,000 \mathrm{~mm}$ per year (Suleiman and Al-Bakri, 2011).

Desert vegetation in the region is very sparse and mostly confined to the dry wadi beds. However, steppe vegetation occurs only $30 \mathrm{~km}$ to the northwest at the higher altitudes of the eastern Wadi Araba-Dead Sea rift shoulder (Palmer, 2013).

Lower Palaeolithic to Epipalaeolithic artefacts are mostly scattered on the deflated surface in the Jurf ed Darawish region and testify the long history of human presence (Bender, 1968; MacDonald et al., 2000; MacDonald et al., 2001). Current land use is mostly restricted to quarrying of building stones, goat husbandry and small-scale irrigation gardening in the village.

\section{MATERIAL AND METHODS}

\section{Logging and Sampling of Sections}

Two adjacent sediment sections were investigated and sampled at naturally exposed steep wadi slopes (Figure 2). One of the investigated sediment sections represents the "type section of the Burma Member from site 3" which was included in a survey of eight different sediment exposures in the region by Moumani et al. (2003, p. 231). We followed the numbering of Moumani et al. (2003) and called the re-sampled sediment sequence "Section 3" and the newly investigated location "Section 9". The two sediment sections are $130 \mathrm{~m}$ apart, and laterally partly traceable sedimentary beds are separated by an incised wadi of ca. $40 \mathrm{~m}$ width (Figure 2).

The columnar sedimentary Section 3 and Section 9 were logged and sediments from freshly cleaned surfaces sampled for micropalaeontological analysis at $23-\mathrm{cm}$ and $37-\mathrm{cm}$ intervals on average, respectively. Sampling focussed on the non-gravelly sediments at both sections. Sampling density was higher in finer-grained greyish-green sedimentary units presumed to represent the lake sediments described by Moumani (1996), Moumani et al. (2003) and Neeley (2004), in comparison to more brownish sediments possibly representing marsh deposits. However, specific sampling positions also depended on exposure conditions and accessibility. Ca. $250 \mathrm{~g}$ of sediment was collected at each sampling location. The position of flaked artefacts, embedded in situ in sediments at the Section 9 and partly also distributed in laterally corresponding sediments nearby, was recorded by a handheld GPS device and a Leica DISTO D8 distance-measuring device.

\section{Optically Stimulated Luminescence Dating}

Samples for OSL dating were collected from Section 3 and Section 9. Steel tubes were hammered into freshly cleaned and shaded section surfaces. Samples from Section 3 were dated in the Luminescence Dating Laboratory of the China University of Geosciences in Wuhan, and samples from Section 9 in the OSL Dating Laboratory at the Geological Survey of Israel to distribute workload. Comparability of age data was ensured by both lab heads, Zhongping Lai and Naomi Porat, by adapting very similar protocols and using the same water contents for the age calculation of samples from both sections (Table 1).

Preparation of OSL samples from Section 3 followed the procedures of Lai and Wintle (2006). Samples were treated with $10 \% \mathrm{HCl}$ and $30 \% \mathrm{H}_{2} \mathrm{O}_{2}$ to remove carbonates and organics, respectively. After wet sieving, the coarse silt fraction of $38-63 \mu \mathrm{m}$ was etched by $35 \% \mathrm{H}_{2} \mathrm{SiF}_{6}$ for about ten days to remove feldspars. Infrared (IR; $830 \mathrm{~nm}$ ) stimulation was used to check for quartz purity, and samples with obvious IR stimulated luminescence signals were treated with $\mathrm{H}_{2} \mathrm{SiF}_{6}$ again to avoid $\mathrm{D}_{\mathrm{e}}$ underestimation (Lai and Brückner, 2008). The purified quartz grains were then mounted on the center $(\sim 0.5 \mathrm{~cm}$ diameter $)$ of stainless steel discs ( $1 \mathrm{~cm}$ diameter) using silicone oil.

OSL measurements of OSL samples from Section 3 were made using an automated Risø TL/OSL-DA-20 reader equipped with blue diodes $(\lambda=470 \pm 20 \mathrm{~nm})$ and infrared laser diodes $(\lambda=$ $830 \mathrm{~nm})$. Measurement details are given in Table $\mathbf{1}$.

The concentrations of $\mathrm{U}$, Th and $\mathrm{K}$ were measured by neutron activation analysis. For the $38-63 \mu \mathrm{m}$ grains, the alpha efficiency value was taken as $0.035 \pm 0.003$ (Lai et al., 2008). The cosmic-ray dose rate was estimated for each sample as a function of depth, altitude and geomagnetic latitude (Prescott and Hutton, 1994). Water content was taken as $25 \pm 5 \%$.

For the equivalent dose $\left(D_{\mathrm{e}}\right)$ determination in Section 3, the combination of the single aliquot regenerative dose (SAR) protocol (preheat of $10 \mathrm{~s}$ at $220^{\circ} \mathrm{C}$, a test dose of $\sim 11.5 \mathrm{~Gy}$ and a test dose preheat of $10 \mathrm{~s}$ at $200^{\circ} \mathrm{C}$ ) and the Standardized Growth Curve (SGC) method was employed (Murray and Wintle, 2000; Roberts and Duller, 2004; Lai, 2006). For each sample, six aliquots were measured using the full SAR protocol to obtain six dose response curves which were then averaged to construct a SGC for this individual sample. Then, more aliquots (from 18 to 22) were measured to obtain the values of test-dose corrected natural signals, and each of the values was interpolated on the SGC to obtain a $D_{e}$. The final $D_{e}$ is the mean of all SAR $D_{e} s$ and $S G C D_{e} s$ (total of 24-28). Further details of the measurement protocol such as preheat conditions are provided in Table 1.

Samples for OSL dating from Section 9 were prepared using the routine protocol of Faershtein et al. (2016). Briefly, the very fine sand of $88-125 \mu \mathrm{m}$ quartz fraction was extracted by sieving, dissolving carbonates with $10 \% \mathrm{HCl}$, and removing heavy minerals by magnetic separation. Feldspars were dissolved and quartz grains etched with $42 \% \mathrm{HF}$ for $40 \mathrm{~min}$, followed by soaking in $16 \% \mathrm{HCl}$ to dissolve any fluorides which may have precipitated.

Dose recovery tests of OSL samples from Section 9 over a range of preheats showed that a recovery of $100 \%$ can be obtained using a preheat of $10 \mathrm{~s}$ at $220^{\circ} \mathrm{C}$, a test dose of $\sim 9.3 \mathrm{~Gy}$ and a test dose preheat of $5 \mathrm{~s}$ at $200^{\circ} \mathrm{C}$. These measurement conditions were used for all samples.

$\mathrm{D}_{\mathrm{e}}$ was measured on 2-mm aliquots with $\sim 200$ grains on the disc. Between 13 and 22 aliquots were measured per sample using a modified SAR protocol (Table 1; Murray and Wintle, 2000). The average $\mathrm{D}_{\mathrm{e}}$ and errors were calculated using the Central Age Model (Galbraith and Roberts, 2012). Single grains (SG) were measured for two samples with a large scatter (JED-2 and JED-4), using green laser stimulation and the same protocol as for the 
TABLE 1 | OSL measurement protocols for the two laboratories. The ratios between the signals measured at steps 3 and 6 were used to construct the dose response curve and calculate the $D_{e}$. At the GSI at least six dose points were used, including two zero-dose points and one recycling point. All samples showed recycling ratios within $10 \%$ of 1.0 for most aliquots and negligible infrared signals. For multi-grain measurements, both labs used blue LEDs for stimulation, and the signal was detected through a 7.5-mm thick U-340 filter (detection window 275-390 nm). For single grain measurements, a green laser was used for stimulation, and detection was as for multi-grains. Irradiations were carried out using calibrated ${ }^{90} \mathrm{Sr} /{ }^{90} \mathrm{Y}$ beta sources.

\begin{tabular}{|c|c|c|}
\hline & $\begin{array}{c}\text { The Geological Survey } \\
\text { of Israel, Jerusalem (Section 9) }\end{array}$ & $\begin{array}{c}\text { China University of } \\
\text { Geosciences, Wuhan (Section 3) }\end{array}$ \\
\hline Grain size & $88-125 \mu \mathrm{m}$ & $38-63 \mu \mathrm{m}$ \\
\hline Discs/cups & Aluminum discs & Stainless steel discs \\
\hline Aliquot size & $2 \mathrm{~mm}$ & $5 \mathrm{~mm}$ \\
\hline Signal and background & First $0.2 \mathrm{~s}$ and last $5 \mathrm{~s}$ & First $0.64 \mathrm{~s}$ and last $5 \mathrm{~s}$ \\
\hline Step & - & - \\
\hline 1 & $\beta$ dose ( 0 for the first run) & $\beta$ dose \\
\hline 2 & Preheat at $220^{\circ} \mathrm{C}$ for $10 \mathrm{~s}$ & Preheat at $220^{\circ} \mathrm{C}$ for $10 \mathrm{~s}$ \\
\hline 3 & Blue stimulation at $125^{\circ} \mathrm{C}$ for $40 \mathrm{~s}(\mathrm{Lx})$ & Blue stimulation at $130^{\circ} \mathrm{C}$ for $40 \mathrm{~s}(\mathrm{Lx})$ \\
\hline 4 & Test dose (9.3 Gy) & Test dose (11.5 Gy) \\
\hline 5 & Preheat at $200^{\circ} \mathrm{C}$ for $5 \mathrm{~s}$ & Preheat at $200^{\circ} \mathrm{C}$ for $10 \mathrm{~s}$ \\
\hline 6 & Blue stimulation at $125^{\circ} \mathrm{C}$ for $40 \mathrm{~s}(\mathrm{Tx})$ & Blue stimulation at $130^{\circ} \mathrm{C}$ for $40 \mathrm{~s}(\mathrm{Tx})$ \\
\hline 7 & Heat at $280^{\circ} \mathrm{C}$ for $100 \mathrm{~s}$ & - \\
\hline
\end{tabular}

multi-grain measurements. In total, 500 grains were measured for each sample and selection criteria followed Porat et al. (2006). The finite mixture model was used to isolate the most significantly bleached fraction from the grain population, and the youngest component greater than $15 \%$ was selected.

Water contents were estimated at $50 \%$ of the saturation-water contents, with associated errors of $\pm 25 \%$ of the estimated value. Saturation-water contents, determined using undisturbed sediment samples in the laboratory, represent the water content of the sediments after deposition in the water body and prior to the incision of the modern Wadi El Jurf. Subsequent sediment exposure and the resulting decrease of pore-water contents was accounted for by using $50 \%$ of the saturation-water contents as average geological moisture contents.

The alpha, beta and gamma dose rates were calculated from the radioactive elements measured by ICP-MS ( $\mathrm{U}$ and Th) or ICP-OES (K). Alpha efficiency value was taken as $0.10 \pm 0.02$ (Aitken, 1985). However, due to HF etching the choice of this value does not affect the ages significantly. Cosmic dose rates were evaluated from the estimated burial depths prior to the downcutting of the modern channels. For samples JED-12-1 to 4, burial depth was estimated at $11 \pm 2 \mathrm{~m}$ based on the thickest preserved sedimentary sequence above the sampled sediments (Figure 2A); and the calculated cosmic dose rate was $64 \pm$ $13 \mu \mathrm{Gy} / \mathrm{a}$ (Table 2).

For comparison with ages originally calculated by Moumani et al. (2003) using water contents of ca. $2 \%$, their three ages from Section 3 were recalculated using the data provided in their Table 1 and water contents of $25 \%$, a more realistic value for such fine-grained sediments, that was also used in our age calculations.

\section{Grain-Size Analysis}

Subsamples of ca. $50 \mathrm{~g}$ from the newly investigated, artefact-rich and thicker sediment Section 9 were used for grain-size analysis with a Coulter LS 200 laser-particle sizer at the Alfred Wegener
Institute for Polar and Marine Research in Potsdam, Germany. Subsamples were split in two halves. One group of subsamples was treated with $10 \%$ acetic acid to remove carbonate. Carbonate was not removed for the second group of subsamples since we initially assumed that a significant portion of the detrital grains are possibly derived from the local Maastrichtian and Eocene limestone bedrock. Both subsample sets were treated with 35\% $\mathrm{H}_{2} \mathrm{O}_{2}$ to remove organic matter. The dispersant $\mathrm{Na}_{4} \mathrm{P}_{2} \mathrm{O}_{7}$ was added to disaggregate the material before grain-size analysis started. Carbonate-free and carbonate-containing samples did not yield significantly different results, and data reported in the following are based on carbonate-free materials. More detailed information is provided in Röhl (2015).

Analysis of total organic carbon (TOC) and total inorganic carbon (TC) concentrations of eight and 25 samples from Section 3 and Section 9, respectively, were measured on powdered samples with an EuroVector EA3000 elemental analyser (detection limit $0.01 \%$ ) at the Institute of Geosciences of the University of Potsdam.

\section{Analysis of Organism Remains}

Subsamples of ca. $200 \mathrm{~g}$ from Section 3 and Section 9 were used for micropalaeontological analysis. Samples were weighed, soaked in a $3 \%$ solution of $\mathrm{H}_{2} \mathrm{O}_{2}$ for two to three days until the reaction was completed, and sieved through 100, 250 and $1000-\mu \mathrm{m}$ sieves. Fossils were picked under an Olympus SZ-60 microscope and selected fossils were documented with a Zeiss Supra $40 \mathrm{VP}$ scanning electron microscope (SEM) at the Institute of Geological Sciences at Free University of Berlin. Two different ostracod taxa of the genus Ilyocypris were identified based on the location and number of marginal ripplets on the inner lamella (Van Harten, 1979; Janz, 1994). These valve features are only visible using a SEM. Thus, valves of Ilyocypris identified with a low-power binocular microscope were pooled as Ilyocypris spp. Identification of other ostracod valves is based on Meisch (2000) and Fuhrmann (2012). 
TABLE 2 | OSL dating results for samples from Section 9 (OD-over-dispersion, the scatter beyond analytical errors. The OD values are low (indicating a homogenous sample) to intermediate (with possible partial bleaching). No. aliquots - the number of aliquots used for the average $D_{e}$ out of the aliquots measured).

\begin{tabular}{|c|c|c|c|c|c|c|c|c|c|c|c|c|c|c|}
\hline $\begin{array}{l}\text { Code } \\
\text { JED }\end{array}$ & $\begin{array}{c}\text { Burial } \\
\text { depth } \\
\text { (m) }\end{array}$ & $\begin{array}{c}\text { Water } \\
\text { content } \\
(\%)\end{array}$ & $\begin{array}{c}K \\
(\%)\end{array}$ & $\underset{\text { (ppm) }}{U}$ & $\begin{array}{c}\text { Th } \\
\text { (ppm) }\end{array}$ & $\begin{array}{c}\text { Ext. } \\
\alpha \\
(\mu \mathrm{Gy} / \mathrm{a})\end{array}$ & $\begin{array}{c}\text { Ext. } \\
\beta \\
\text { ( } \mu \mathrm{Gy} / \mathrm{a})\end{array}$ & $\begin{array}{c}\text { Ext. } \\
\gamma \\
\text { ( } \mu \mathrm{Gy} / \mathrm{a})\end{array}$ & $\begin{array}{l}\text { Cosmic } \\
(\mu G y / a)\end{array}$ & $\begin{array}{c}\text { Dose } \\
\text { rate } \\
(\mu \mathrm{Gy} / \mathrm{a})\end{array}$ & $\begin{array}{l}\text { No. } \\
\text { aliquots }\end{array}$ & $\begin{array}{l}\text { OD } \\
(\%)\end{array}$ & $\begin{array}{l}D_{e} \\
\text { (Gy) }\end{array}$ & Age (ka) \\
\hline $12-1$ & 11.0 & 26 & 1.00 & 2.4 & 7.8 & 9 & 917 & 683 & 64 & $1,674 \pm 54$ & $22 / 22$ & 33 & $108 \pm 8$ & $64 \pm 5$ \\
\hline $12-2$ & 11.0 & 24 & 1.08 & 2.7 & 8.2 & 10 & 1,017 & 742 & 64 & $1843 \pm 63$ & $8 / 10$ & 47 & $124 \pm 16$ & $67 \pm 9$ \\
\hline SG & - & - & - & - & - & - & - & - & - & - & $126 / 500$ & 56 & $122 \pm 5$ & $66 \pm 3$ \\
\hline $12-3$ & 11.0 & 25 & 1.25 & 2.4 & 9.0 & 10 & 1,083 & 781 & 64 & $1938 \pm 64$ & $20 / 20$ & 20 & $148 \pm 7$ & $76 \pm 5$ \\
\hline $12-4$ & 11.0 & 15 & 0.48 & 2.7 & 4.0 & 9 & 669 & 523 & 64 & $1,264 \pm 39$ & $12 / 13$ & 46 & $113 \pm 14$ & $89 \pm 11$ \\
\hline SG & - & - & - & - & - & - & - & - & - & - & $152 / 500$ & 51 & $106 \pm 4$ & $84 \pm 4$ \\
\hline $12-5$ & 1.0 & 10 & 0.64 & 2.6 & 4.6 & 10 & 808 & 600 & 185 & $1,602 \pm 49$ & $20 / 20$ & 14 & $70 \pm 3$ & $44 \pm 2$ \\
\hline
\end{tabular}

\section{RESULTS}

The exposed sediments at the Section 3 and Section 9 are mostly yellowish-brown, homogenous silts. Thick gravel beds occur at the base and thinner gravel layers are exposed within the sections and at their tops (Figure 3, Supplementary Figure S1). Vertical voids, casts and colourations of a few millimetres to $1-\mathrm{cm}$ diameter are abundant at both sections. The silty sediments partly contain granules and small pebbles which are embedded in the fine-grained matrix. The silty sediments are partly greyishgreen in the lower half or middle of both sections; and carbonaterich units of 1 to $85-\mathrm{cm}$ thickness occur at both sections.

In total, 22 artefacts were recognized in a single sedimentary bed ca. $4.5 \mathrm{~m}$ above the base of Section 9 and partly distributed in corresponding sediments over a lateral stretch of $92 \mathrm{~m}$ (Figure 2). The vertical position of the artefacts within the specific artefactbearing layer varies by up to $40 \mathrm{~cm}$. One additional artefact was recognized at $11.6 \mathrm{~m}$ above the base of Section 9 (Figures 2, 3).

The four OSL ages obtained for the artefact-bearing layer at Section 9 range from $84 \pm 4$ ka to $64 \pm 5 \mathrm{ka}$ (Table 2), and are in a stratigraphic order (Figure 3). One additional sample from close to the top of the sediment sequence provided an age of $44 \pm 2 \mathrm{ka}$. The nine OSL ages from Section 3 range from $215 \pm 34 \mathrm{ka}$ at the base of the section to $30 \pm 3 \mathrm{ka}$ near its top (Table 3). Two of the samples are not in a stratigraphic order, perhaps due to poor estimation of the dose rates (Table 2; Figure 3).

Grain-size analysis of the non-gravelly sediments at Section 9 show that silt is the largest grain-size fraction with $42.9 \%$ on average (minimum $32.2 \%$, maximum $59.7 \%$ ), followed by clay (39.3\%; minimum $16.3 \%$, maximum $51.8 \%$ ). Sand constitutes $17.8 \%$ on average (minimum $6.3 \%$, maximum $31.9 \%$; Figure 4 ). The main mode of the grain-size frequency curves of most sediment samples is located at ca. $3 \mu \mathrm{m}$, and two sub-ordinate modes occur at ca. 50 and $150 \mu \mathrm{m}$ (Figure 5).

TOC concentrations at Section 3 are $0.10 \%$ on average (minimum $0.08 \%$, maximum $0.12 \%$ ) and $0.11 \%$ at Section 9 (minimum $0.04 \%$, maximum $0.21 \%$ ). TIC concentration is $4.60 \%$ on average at Section 3 and $4.01 \%$ at Section 9 (minima are 2.69 and $1.01 \%$, and maxima are 6.71 and $8.15 \%$, respectively; Figure 4).
In total, 11 ostracod taxa, remains of one bivalve, shells of two aquatic and two terrestrial gastropod taxa, gastropod opercula, and charophyte gyrogonites were recorded in sediment samples from Section 9 (Figure 6). In addition, Cretaceous ostracod valves and carapaces, foraminifera tests and scaphopod fragments were recorded in the lowermost samples from the section. Valves and carapaces of Potamocypris fulva are the most abundant ostracod remains (total number of valves including articulated valves: $n_{v}=$ $423)$, followed by unidentified valves of juvenile Candoninae $\left(n_{v}\right.$ $=194)$, remains of Ilyocypris spp. $\left(n_{v}=91\right)$ and those of Pseudocandona sp. $\left(n_{v}=76\right)$. Most abundant gastropod remains are represented by opercula $(n=19)$. The majority of fossil remains was recorded from the lower half of Section 9 (Figure 6).

At Section 3, 11 ostracod taxa, shells of two aquatic and two terrestrial gastropod taxa, and charophyte gyrogonites were recorded (Figure 7). A single Cretaceous ostracod valve, foraminifera tests and scaphopod fragments were recorded in addition. Most Quaternary ostracod remains belong to unidentified juvenile valves and carapaces of Candoninae $\left(n_{v}=\right.$ $860)$, to Ilyocypris spp. $\left(n_{v}=247\right)$ and to Heterocypris salina $\left(n_{v}=\right.$ 50; Figures 8, 9). Ostracod remains were almost exclusively recorded from the lower half of the sediment section (Figure 7). Four shells of the terrestrial gastropod family Ferussaciidae were recorded in the upper half of the section, and eight gyrogonites from samples from the lower half. Abundances of all other Quaternary non-ostracod remains at the Section 3 are lower (Figure 7).

\section{DISCUSSION}

\section{The Age of the Investigated Sediments}

A total of 14 samples provide a stratigraphic framework for the two studied sections at Jurf ed Darawish, in addition to the published ages by Moumani et al. (2003) which were recalculated using higher water contents. Three newly determined ages between ca. 100 and more than $200 \mathrm{ka}$, and the recalculated age of ca. $150 \mathrm{ka}$ of Moumani et al. (2003) near the base of Section 3 , represent minimum ages because $D_{e}$ values higher than 


\section{Section 3}
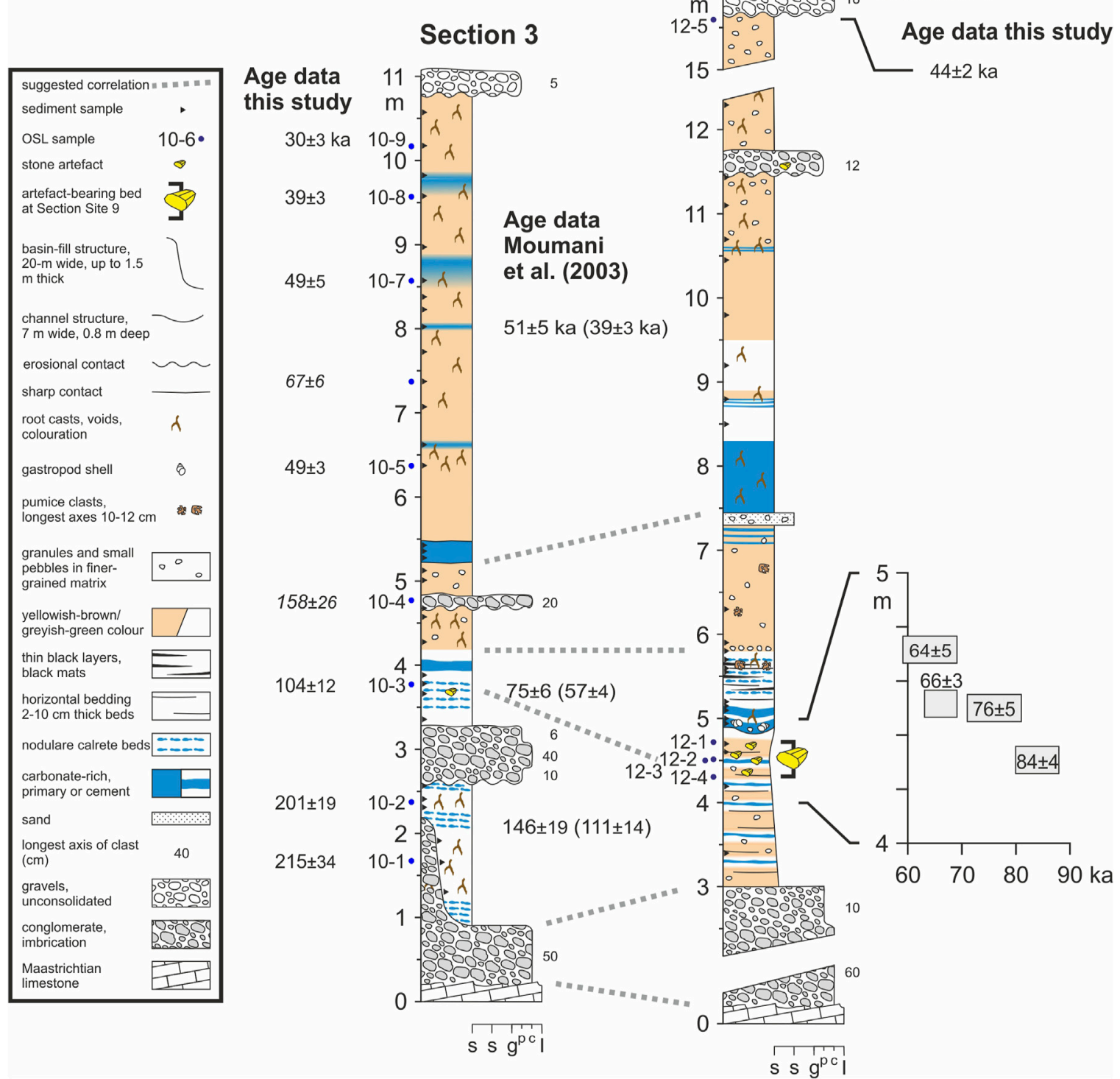

FIGURE 3 | Lithology and OSL age data of Section 3 and Section 9. Positions of three previously dated samples and artefact-bearing layer at Section 3 according to Moumani et al. (2003). In-situ artefacts were only recorded at Section 9 in this study. Age data originally reported by Moumani et al. (2003) in brackets, calculated with water contents of ca. $2 \%$, were recalculated using water contents of $25 \%$ to enable comparability. The lower three newly obtained age data from Section 3 are minimum ages. Age data of Section 3 in italics are not in stratigraphic order, perhaps due to inaccurate dose rates (Table 3). Photos of sections and complete lithological log of Section 9 is available as Supplementary Figure S1. (scale of $x$-axis s s g p c l: silt, sand, granules, pebbles, cobbles, limestone, respectively)

$\sim 150$ Gy are considered as underestimated due to the approach of the dose response curve to saturation (Faershtein et al., 2020; Table 3). The minimum ages suggest that the onset of the accumulation of fine-grained sediments pre-dates the Late Pleistocene (Figure 3). This onset occurred apparently in the Middle Pleistocene or even earlier.

Sediments near the base of Section 9 provided ages of ca. $85 \mathrm{ka}$ and younger. The age data indicate that the lowermost fine-grained sediments at both sections accumulated during MIS 5 and/or earlier. The stratigraphically mostly consistent ages from the middle and upper part of Section 3 suggest that the accumulation of fine-grained sediments lasted at least until ca. $30 \mathrm{ka}$, in the later part of MIS 3 (Figure 3). The recalculated age of $\sim 50 \mathrm{ka}$ for a sample investigated by Moumani et al. (2003) from a position ca. $2 \mathrm{~m}$ below our uppermost OSL sample at Section 3, and the age of $44 \mathrm{ka}$ from Section 9, are all stratigraphically consistent.

Four sediment samples from the artefact-bearing bed at Section 9 yielded stratigraphically consistent ages between ca. 85 to $65 \mathrm{ka}$, suggesting that humans were present in the region 
TABLE 3 | OSL dating results for samples from Section 3 (alpha counting was not used; No. aliquots - the number of aliquots used for the average $D_{e}$ out of the aliquots measured).

\begin{tabular}{|c|c|c|c|c|c|c|c|c|c|}
\hline $\begin{array}{l}\text { Code } \\
\text { JED }\end{array}$ & $\begin{array}{c}\text { Burial } \\
\text { depth } \\
\text { (m) }\end{array}$ & $\begin{array}{c}\text { Water } \\
\text { contents } \\
(\%)\end{array}$ & $\begin{array}{c}K \\
(\%)\end{array}$ & $\begin{array}{c}\mathbf{U} \\
\text { (ppm) }\end{array}$ & $\begin{array}{c}\text { Th } \\
\text { (ppm) }\end{array}$ & $\begin{array}{c}\text { Dose } \\
\text { rate } \\
\text { ( } \mu \mathrm{G} / \mathrm{a})\end{array}$ & $\begin{array}{c}\text { No. } \\
\text { aliquots }\end{array}$ & $\begin{array}{l}D_{e} \\
\text { (Gy) }\end{array}$ & Age (ka) \\
\hline $10-1$ & 9.4 & 25 & 0.66 & 3.8 & 5.6 & $1,666 \pm 119$ & 28 & $359 \pm 50$ & $215 \pm 34^{\star}$ \\
\hline $10-2$ & 8.7 & 25 & 0.77 & 1.2 & 6.0 & $1,468 \pm 105$ & 28 & $294 \pm 19$ & $201 \pm 19^{\star}$ \\
\hline $10-3$ & 7.3 & 25 & 0.81 & 2.0 & 7.1 & $1,506 \pm 106$ & 28 & $157 \pm 14$ & $104 \pm 12^{*}$ \\
\hline $10-4$ & 6.3 & 25 & 0.36 & 1.4 & 2.9 & $812 \pm 71$ & 26 & $128 \pm 18$ & $158 \pm 26$ \\
\hline $10-5$ & 4.7 & 25 & 0.83 & 2.1 & 5.3 & $2,150 \pm 117$ & 28 & $104 \pm 4$ & $49 \pm 3$ \\
\hline $10-6$ & 3.7 & 25 & 0.99 & 2.0 & 5.4 & $1,584 \pm 110$ & 22 & $106 \pm 7$ & $67 \pm 6$ \\
\hline $10-7$ & 2.5 & 25 & 0.79 & 1.8 & 5.0 & $1,387 \pm 97$ & 24 & $68 \pm 5$ & $49 \pm 5$ \\
\hline $10-8$ & 1.5 & 25 & 0.85 & 2.1 & 6.1 & $1,608 \pm 109$ & 24 & $63 \pm 3$ & $39 \pm 3$ \\
\hline $10-9$ & 0.9 & 25 & 0.92 & 2.7 & 6.1 & $1794 \pm 119$ & 24 & $54 \pm 3$ & $30 \pm 3$ \\
\hline
\end{tabular}

*Minimum age.

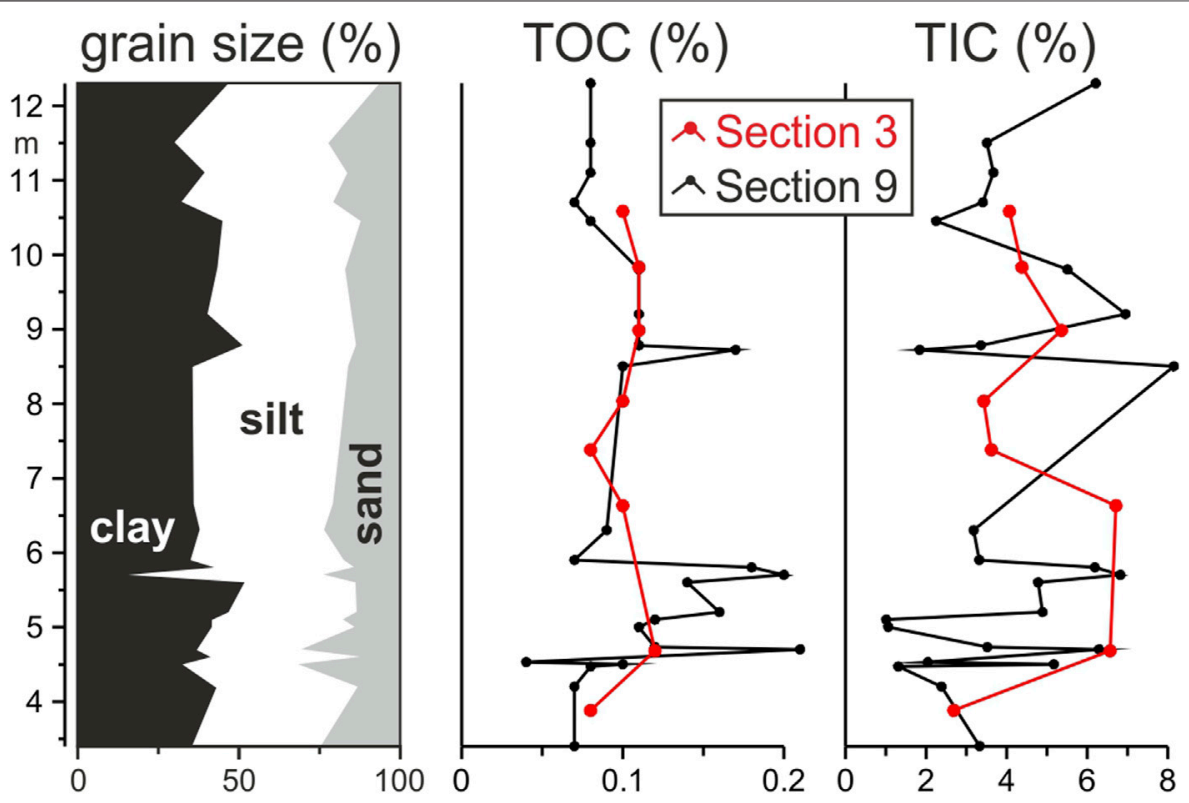

FIGURE 4 | Grain-size fractions at Section 9, and concentrations of total organic (TOC) and inorganic (TIC) carbon. TOC and TIC concentrations at Section 3 shown for comparison in red. Note: TOC and TIC concentrations are shown at height above section base, the data do not necessarily correlate stratigraphically.

during a relatively long period of ca. $20 \mathrm{ka}$ in the later part of MIS 5 and first half of MIS 4. The recalculated age of the sample collected by Moumani et al. (2003) from the artefact-bearing deposits at Section 3, ca. $75 \mathrm{ka}$, supports the age range for the artefact-bearing sediments at Section 9. In contrast, we determined a significantly older minimum age of ca. $105 \mathrm{ka}$ for the sediments considered to contain artefacts at Section 3. However, this older age potentially results from 1) a stratigraphically lower position of the sampled material in comparison to the sediment with the embedded artefacts dated by Moumani et al. (2003), 2) sampling of a laterally inconsistent sediment layer which pre-dates the accumulation of the artefactbearing sediment dated by Moumani et al. (2003), or 3) an earlier occupation period than those represented by artefacts in Section 9.

\section{The Depositional Setting at Jurf ed Darawish}

The sediments at the two sections represent three main types: 1) gravel deposits, 2) massive yellowish-brown clayey silts with casts, voids or colour traces of roots, and 3) greyish-green clayey silts which are partly carbonate-rich, partly characterized by horizontal bedding and which partly include thin, darker layers (Figures 3, 4). The gravelly deposits were formed either in river channels by fast-flowing water or by overland flow during sporadic flash floods. The thick gravel beds in the lower part of both sections include clasts with up to $60-\mathrm{cm}$ long axes, indicating fast flow. Thinner gravel beds intercalated in the sedimentary sequences and the gravel cover at the top of the sections, which is wide-spread on the surface in the region, probably originate from flash floods. 

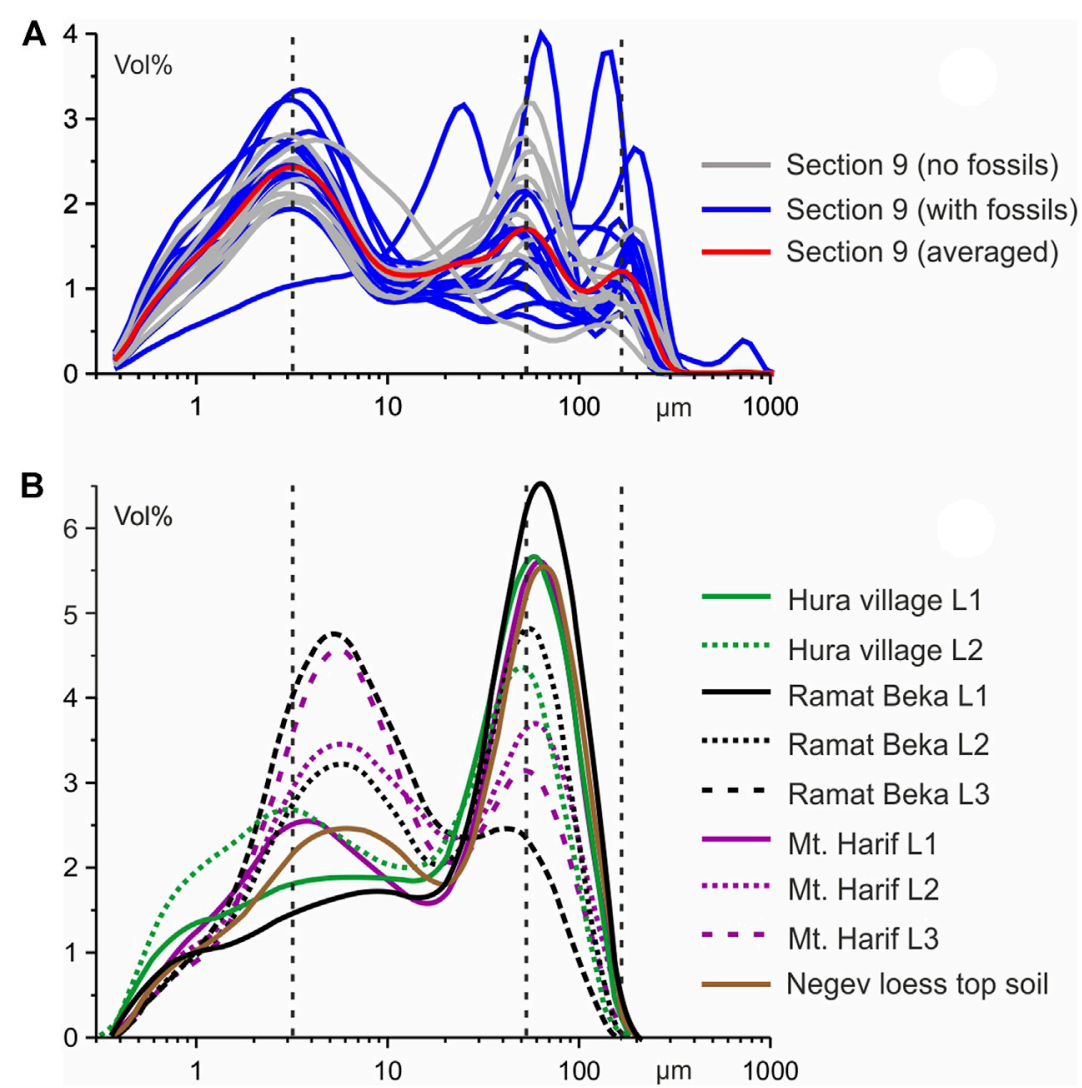

FIGURE 5 | (A) Grain-size-frequency curves for sediment samples from Section 9. Position of three modes at ca. 3, 50 and $150 \mu$ m indicated by vertical dotted lines. (B) Grain-size frequency curves for loess samples from the Negev Desert redrawn from Amit et al. (2020; Negev loess top soil) and Crouvi et al. (2008; all other) for comparison.

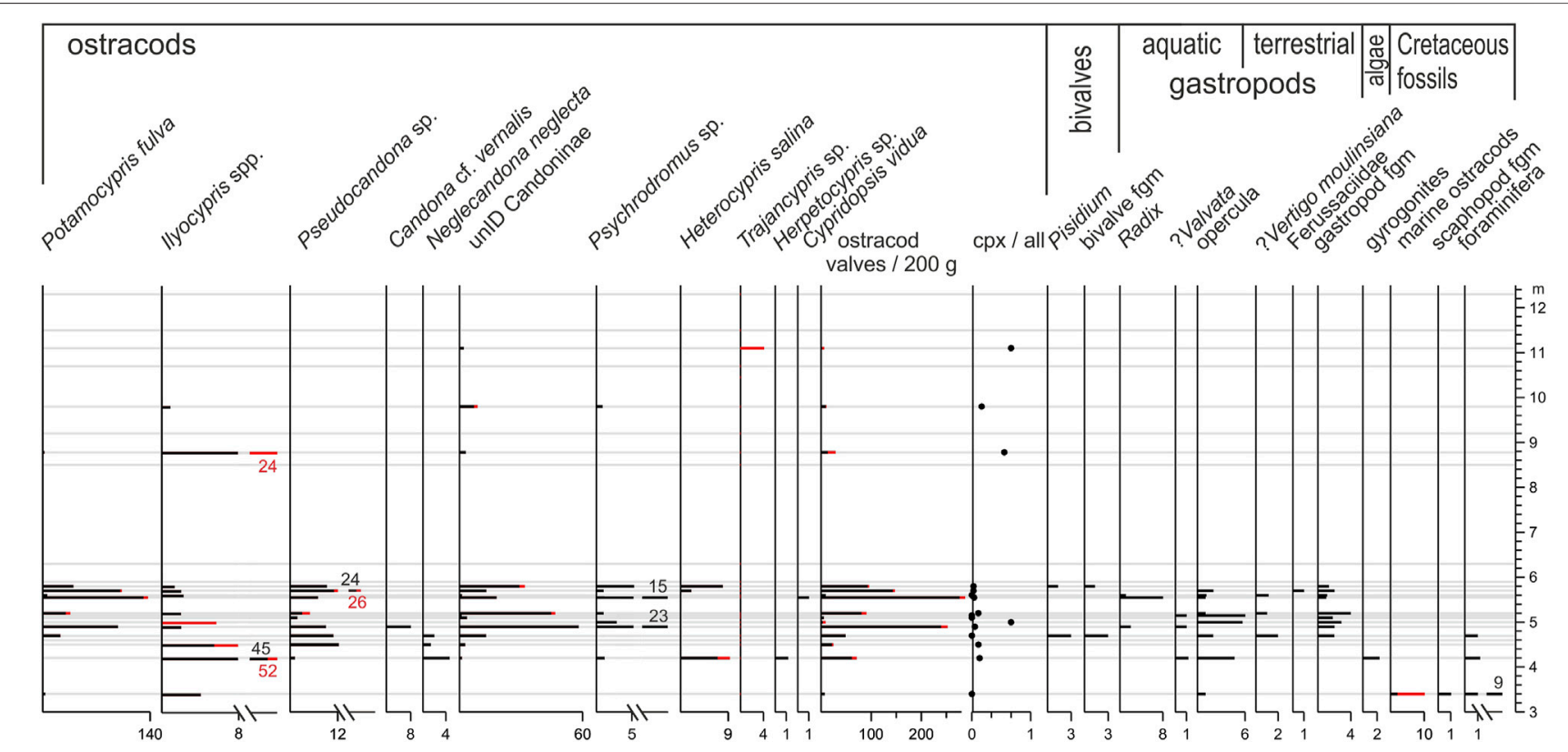

FIGURE 6 | Fossils recorded in sediments of Section 9. Abundances of articulated ostracod valves, i.e., carapaces (cpx), are indicated by red colour. (fgm fragments) 


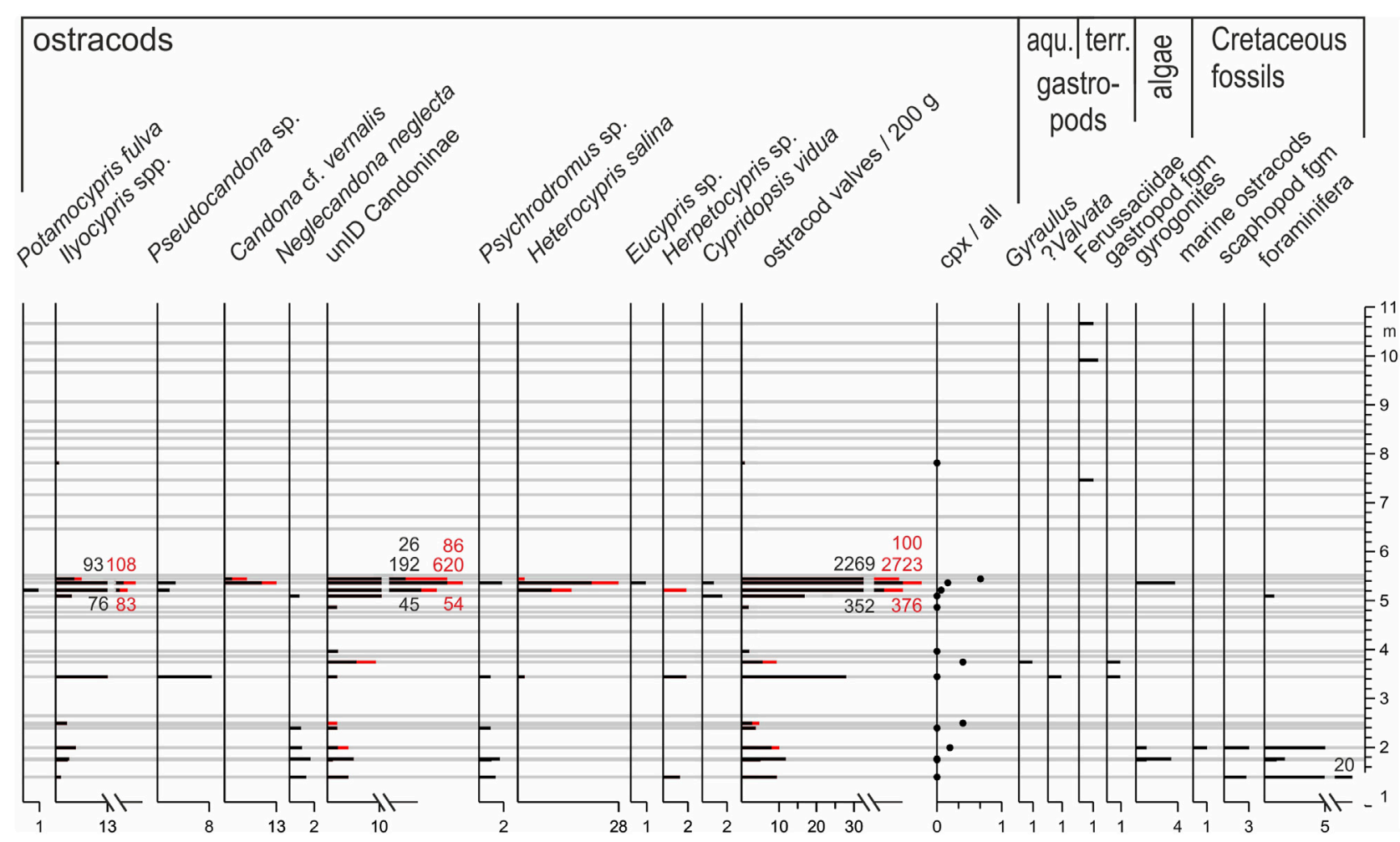

FIGURE 7 | Fossils recorded in sediments of Section 3. Articulated ostracod valves (carapaces, cpx) shown in red as in Figure 6. (fgm fragments)

The massive yellowish-brown clayey silts with casts, voids or colour traces of roots dominate at Section 9 and in the middle and upper part of Section 3 (Figure 3, Supplementary Figure S1). They probably represent reworked alluvial sediments which accumulated in topographically lower locations. The oxidized colour and frequent root traces show that the sediments were mostly exposed and covered by terrestrial plants.

The partly carbonate-rich, partly horizontally bedded greyishgreen clayey silts, mostly in the lower halves of both sections, were probably formed in an aquatic to semi-aquatic depositional setting with carbonate precipitation from the open water surface or from groundwater near the surface. Thin sediment layers with darker colour similar to reported "black mats" in other desert environments indicate formation in wetlands (Quade et al., 1998; Pigati et al., 2014).

The fine-grained sediments of Section 9 do not show significant variations of the clay, silt and sand fractions through the stratigraphic sequence (Figure 4). Accordingly, grain-size frequency curves of individual samples from the section show three modes at more or less constant grain sizes (Figure 5). The two most abundant grain populations characterized by modes at ca. 3 and $50 \mu \mathrm{m}$ resemble the grainsize patterns of loess samples collected from the Negev Desert (Crouvi et al., 2008; Amit et al., 2020; Figure 5). Primary, nonreworked loess in the Negev Desert has a bimodal grain-size frequency distribution with one mode at a fine grain size of $3-8 \mu \mathrm{m}$ and a second mode at a coarser grain size between 50 and
$60 \mu \mathrm{m}$ (Crouvi et al., 2008, 2009). The finer grain population is regarded as transported mainly from far, distal sources (500-2000 km) such as the Sahara and Arabia, with some contribution from proximal sources (Crouvi et al., 2008; Amit et al., 2020). The coarser grains are described as locally derived dust downwind of active dune fields.

Topsoil sediments of the Judean Mountains in the west and northwest of the Dead Sea were investigated by Amit et al. (2020) who concluded that the clastic particles originated mainly from the Sinai-Negev Erg. The bimodal grain-size frequency distributions of these topsoil samples have one mode centered at ca. $5 \mu \mathrm{m}$ and a second mode between 42 and $52 \mu \mathrm{m}$, comparable to the investigated sediments of the Section 9 which have a similar distance to the Sinai-Negev Erg that could be a potential source area.

In contrast to the loess deposits of the Negev Desert and the topsoil sediments of the Judean Mountains, the sediments of Section 9 have an additional third mode in the fine sand fraction which is comparable to aeolian sand deposits in the Arava/Araba Valley to the west of the central Jordanian Plateau or to dune sands in northeastern Saudi Arabia in its east (Saqqa and Atallah, 2004; Benaafi and Abdullatif, 2015; Figure 5). Thus, this coarser grain population probably represents locally derived aeolian sand.

Numerous recorded fossils in the lower part of both sections allow more detailed inferences of the depositional setting. The most abundant fossils, the ostracod assemblages, indicate the existence of a slowly flowing stream and associated wetland 


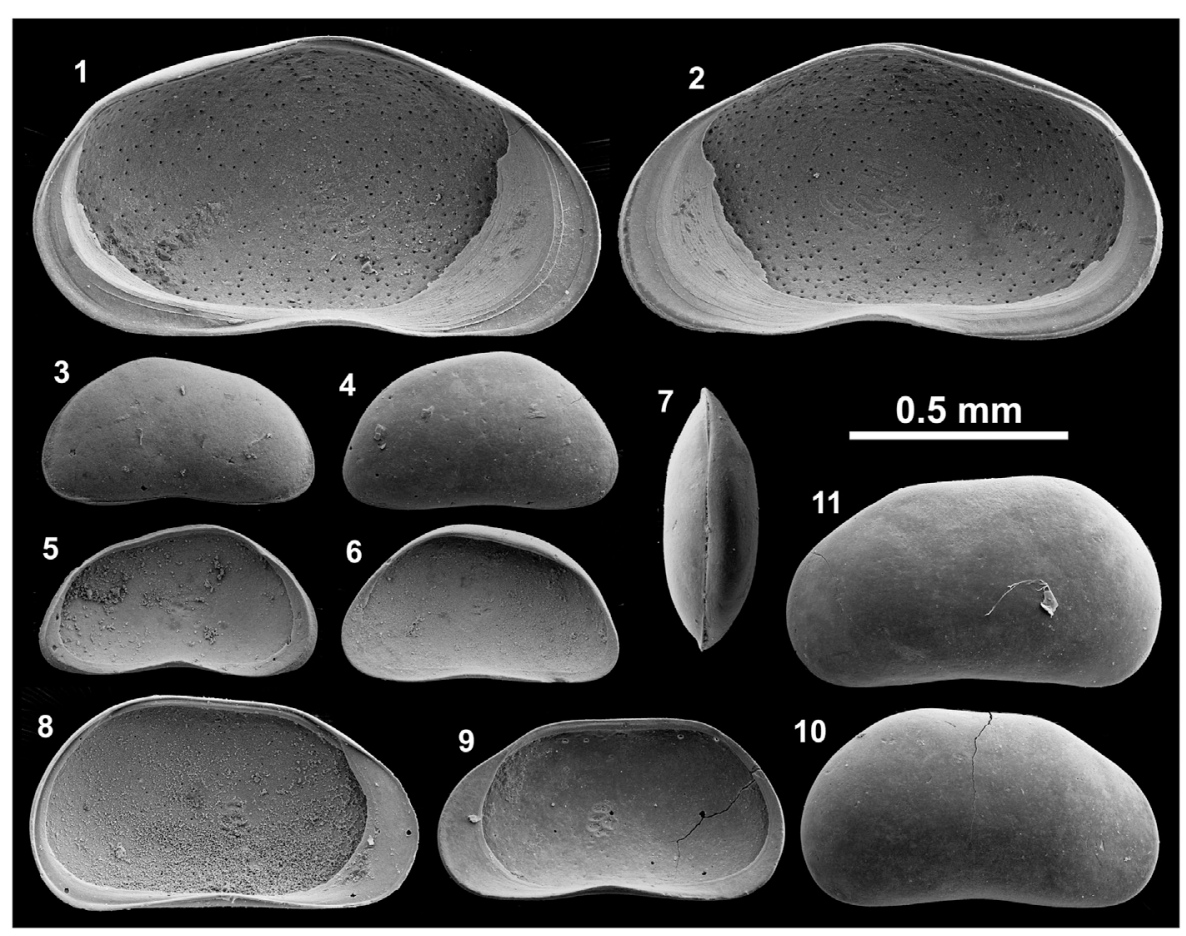

FIGURE 8 | Ostracod valves recorded at Section 9. 1-2 Psychrodromus sp., 1 left valve (LV) internal view (iv), 2 right valve (RV) iv; 3-7 Potamocypris fulva, 3 LV external view (ev), 4 RV ev, 5 LV iv, 6 RV iv, 7 dorsal view of carapace; 8-11 Pseudocandona sp., 8 LV iv, 9 RV iv, 10 RV ev, 11 LV ev. All specimens housed at Institute of Geological Sciences, Free University of Berlin (Germany).

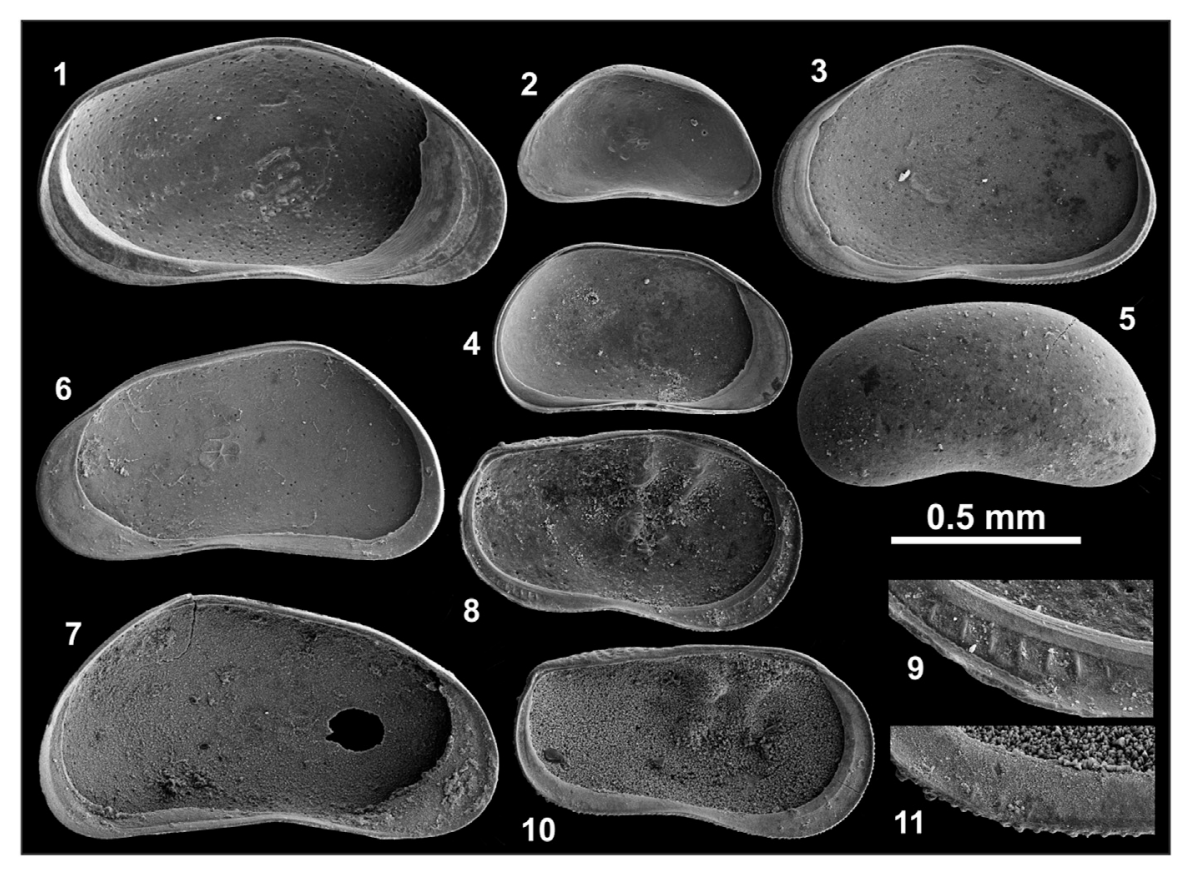

FIGURE 9|Ostracod valves recorded at Section 3. 1 Psychrodromus sp. LV iv; 2 Potamocypris fulva RV iv; 3 Heterocypris salina RV iv; 4 Pseudocandona sp. LV iv; 5 Neglecandona neglecta carapace (LV visible); 6-7 Candona cf. vernalis, 6 RV iv, 7 LV iv; 8-9 llyocypris cf. gibba, 8 LV iv, 9 enlargement of posteroventral part, inner lamella with marginal ripplets; 10-11 Ilyocypris cf. bradyi, 10 LV iv, 11 enlargement of posteroventral part, partly recrystallized and overgrown inner lamella with poorly preserved marginal ripplets. Scale not valid for 9 and 11. Abbreviations as in Panel 9. All specimens housed at Institute of Geological Sciences, Free University of Berlin (Germany). 


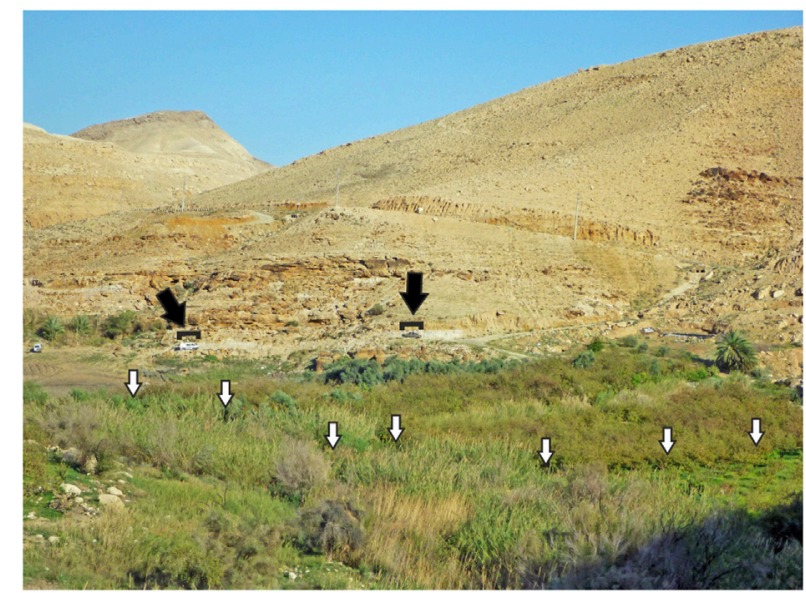

FIGURE $10 \mid$ In-stream wetland in Wadi Hasa ca. $40 \mathrm{~km}$ to the northwest of Jurf ed Darawish. Two cars (black arrows) for scale. Position of stream indicated by white arrows. (Photo by Wolfgang Streicher)

conditions, including springs and temporary ponds at the studied locations. For example, Potamocypris fulva, most abundant at Section 9, is typically recorded from very shallow, slowly flowing waters and the interstitial (subterranean) habitat of streams (Meisch, 2000). Similarly, Ilyocypris gibba and I. bradyi typically occur in small and shallow water bodies such as ponds, springs and streams. Species of Pseudocandona are mostly described from permanent and temporary small water bodies such as ponds and springs and the interstitial habitat of streams (Meisch, 2000). Those of Psychrodromus are mostly reported from springs, streams flowing from springs, and ponds. Heterocypris salina typically inhabits small temporary water bodies. Cypridopsis vidua is specifically known from densely vegetated water bodies. Candona vernalis, resembling the widely distributed Neglecandona neglecta, was only described from modern habitats and Holocene and MIS 9 (Holstein Interglacial ca. $330 \mathrm{ka}$ ) deposits in Central Germany so far (Fuhrmann, 2012). The species occurs in temporary small water bodies, often in river plains. The large variations in the number of ostracod valves per sample correspond with typically seen large lateral changes in a stream and wetland setting rather than the minor gradual changes expected in a lake environment. In analogy to modern in-stream wetlands in some segments of Wadi Hasa ca. $40 \mathrm{~km}$ northwest of Jurf ed Darawish, an in-stream wetland is inferred from the fossils at Section 3 and Section 9 (Figure 10).

The recorded gastropods in sediments of both sections support the inference of a stream and wetland setting due to the occurrence of both aquatic and terrestrial forms. The bivalve genus Pisidium was recorded too, whose members occur in a wide range of habitats typically including small and temporary water bodies, springs, streams and lake margins (Welter-Schultes, 2012).

Although only $130 \mathrm{~m}$ apart from each other, the distribution of fossils at Section 3 and Section 9 does not support a laterally consistent facies distribution and clear correlation of both sedimentary sequences. For example, valves of Potamocypris fulva, abundant at Section 9, were not recorded at Section 3 apart from a single valve (Figures 6, 7). In addition, valves of Pseudocandona sp. and Psychrodromus sp. are both abundant at Section 9 but rare at Section 3. However, these differences in the assemblage data are supported by the field observation of the lateral coarsening of the artefact-bearing bed at Section 9 towards the north. Lateral litho- and biofacies changes are apparently evident in the Jurf ed Darawish region, and expected in an instream wetland setting with slowly flowing waters, stagnant waters, springs and emerged terrestrial habitats occurring close to each other at the same time (Pigati et al., 2014). The inferred lateral facies changes are also evident from the differences of the sedimentary sequences of the Section 3 and Section 9 (Figure 3). In addition, they probably explain the seeming discrepancy of the older OSL age determined for the topmost sediments of Section 9 in comparison to the ages of the uppermost sediments at Section 3 in a topographically lower position (Figure 3).

In contrast to the sediments in the lower parts of both sections, fossils were only sporadically recorded in the deposits above (Figures 6, 7). However, grain-size frequency curves for these samples are not substantially different from the fossil-bearing samples (Figure 5). The middle mode of these samples is more constrained to a grain size of ca. $50 \mu \mathrm{m}$, possibly as a result of less significant changes in flow conditions in comparison to the inferred in-stream wetland conditions for sediments below. Clastic material was apparently washed to a topographic low from nearby source areas. The lack of fossils and the oxidized sediment colour suggest that open, stagnant water was not or only rarely present. Abundant traces of plant roots indicate that terrestrial vegetation likely existed most of the time. The instream wetland was possibly replaced by a vegetated alluvial plain due to reduced surface runoff which probably resulted from decreased precipitation in the catchment, and/or the increasing down-cutting by flowing waters and possibly lowered groundwater. The timing of the transition from an in-stream wetland setting to a vegetated alluvial plain at Jurf ed Darawish is not well constrained. However, the available age data suggest that this transition occurred sometime between ca. 60 to $50 \mathrm{ka}$ possibly contemporaneous with the MIS 4/3 transition.

The similarity of the grain-size-frequency curves of samples from Section 9 and those of loess deposits in the Negev Desert suggests that the detrital source material of sediments at Jurf ed Darawish was local loess derived from the catchment of the former wetland. The presence of fossil remains of aquatic organisms, partly recognized horizontal bedding, the dense appearance of the sediments, and the occurrence of granules and small pebbles in the fine-grained matrix, show that the clayey silts represent reworked, secondary fluvial loess rather than primary loess deposits (Cordova et al., 2005). In contrast to the loess deposits of the Negev Desert with a bimodal grainsize frequency distribution, the sediments at Jurf ed Darawish have a significantly higher proportion of the clay and very fine silt fraction in comparison to the coarse silt fraction, consistent with the larger distance to source areas in comparison to the deposits of the Negev Desert (Crouvi et al., 2008; Amit et al., 2020; Figure 5). 
According to Cordova et al. (2005), primary loess occurs in Jordan in a North-South stretching band which is some tens of kilometres to the east of the highest regions of the Jordanian Plateau and which includes the study area. Red Mediterranean soils are present in the more elevated regions to the west and north of Jurf ed Darawish (Cordova et al., 2005), and Lucke et al. (2013) demonstrated that these soils originated from the longterm accumulation of remote dust (mainly from Egypt and Sudan) rather than the weathering of bedrock.

Periods of dust accumulation are not well constrained in Jordan but studies in the Negev Desert indicate that loess formation occurred as early as the middle Pleistocene ca. $180-130 \mathrm{ka}$, followed by a major phase of dust deposition and loess formation after $80-75 \mathrm{ka}$ which continued throughout MIS 2 (Ben David, 2003; Enzel et al., 2008; Crouvi et al., 2009). Faershtein et al. (2016) suggested that erosion in the Negev Highlands started after a long period of dust aggradation ca. $24 \mathrm{ka}$ and became predominant at the MIS 2/1 transition. The youngest dated fine-grained deposits near the top of Section 3 with an age of ca. $30 \mathrm{ka}$ and the exposed bedrock in the Wadi El Jurf show that a similar transition from aggradation to incision occurred on the Jordanian Plateau sometime during MIS 2 or 1. According to Neeley (2004), archaeological remains in the Jurf ed Darawish region span the lower Palaeolithic through the Early Epipalaeolithic. Younger than Early Epipalaeolithic (19-16 ka) remains are apparently absent due to diminished resources. Thus, archaeological evidence points to a transition from the former aggradational to the present erosional setting during the last few thousand years before the onset of the Holocene.

\section{Discussion of Previous Inferences From Jurf ed Darawish}

The initial investigation of Section 3 and spatial analysis of other nearby sections by Moumani et al. (2003, p. 221) led to the inference of "normal freshwater lacustrine conditions" between $>111$ and <40 ka at Jurf ed Darawish. Moumani et al. traced sediments similar to those exposed at Section 3 as their newly defined Burma Member of the Wadi Hasa Marl Formation in Wadi El Jurf and upstream in Wadi Burma along an 8-km long southwest-northeast oriented stretch. They argued that a minimum lake depth of $15 \mathrm{~m}$ must have existed due to the altitudinal difference of these sediments with an altitude of $940 \mathrm{~m}$ asl at Jurf ed Darawish and $955 \mathrm{~m}$ asl upstream in Wadi Burma. However, they also stated that the sediment types and recorded fossils rather point to a shallow lake of 10$\mathrm{m}$ depth or less. Shoreline features were not recorded. Additional fine-grained sediments, mapped in Wadi Al Juhiera between 1,008 and 1,014 $\mathrm{m}$ asl, ca. $7 \mathrm{~km}$ southwest of Jurf ed Darawish, were regarded as deposits of a separate lake basin since a single lake with a required water depth of ca. $70 \mathrm{~m}$ was considered as unrealistic for the currently hyperarid region. We argue that 1) the altitudinal distribution of sediments similar to those at Section 3 and Section 9 over a range of ca. $70 \mathrm{~m}, 2$ ) their spatial documentation along the modern wadis Al Juhiera, Burma and El Jurf, 3) the lack of shoreline deposits, and 4) the sediment types and included fossils recorded at Section 3 and
Section 9 are evidence for the former existence of in-stream wetlands and aggradational alluvial plains in the Pleistocene. Similar in-stream wetlands occur in some segments of Wadi Hasa $40 \mathrm{~km}$ to the northwest of Jurf ed Darawish today, showing that only slight differences in local climate and groundwater hydrology are required to support a different landscape in an aggradational setting at Jurf ed Darawish (Figure 10). In contrast, far-reaching inferences such as those by Findlater (2003, p. 59) who compared the Late Pleistocene landscape at Jurf ed Darawish with a "jungle-like terrain" and nearest modern analogues "in central Africa or South East Asia" are clearly not supported by the accumulated geological evidence.

\section{Comparison With Other Pleistocene Records in the Region}

Intensive archaeological surveys and geological studies were conducted in the upper reaches of Wadi Hasa only $20 \mathrm{~km}$ to the north of Jurf ed Darawish since the initial surveys by Vita-Finzi (1964) and Clark (1984; Figure 1). As a result, Schuldenrein and Clark (1994) and Schuldenrein and Clark (2003) suggested that a relatively large lake existed in the region in the second half of the Late Pleistocene between ca. 70 to $20 \mathrm{ka}$. However, the detailed sedimentological and dating study of Winer (2010) demonstrated that the sediments in question where formed in an in-stream wetland setting (Rech et al., 2017). Inferred periods of sediment accumulation were before ca. 140, at ca. 120, 98-78, 68-50, 32-24, 16-13 and 10-7 ka (Winer, 2010; Figure 11). Remains of gazelle and equids from 'Ain Difla in Wadi Ali, a small tributary of Wadi Hasa, were assigned an age of ca. $100 \mathrm{ka}$, and suggest that a cool steppe or sub-desert environment existed in the region in the early Late Pleistocene which is more consistent with the inference of in-stream wetlands rather than a longterm presence of a large lake in the Wadi Hasa region (Lindly and Clark, 1987; Shea, 2003).

A lake of ca. 1,000-1,800 $\mathrm{km}^{2}$ size was also proposed for the $\mathrm{Al}$ Jafr Basin ca. $60 \mathrm{~km}$ to the southeast of Jurf ed Darawish, based on geomorphological analyses and the examination of surficially exposed sediments by Huckriede and Wiesemann (1968), Bender (1968) and Bandel and Salameh (2013; Figure 1). Sediment sections of the uppermost $2 \mathrm{~m}$ were subsequently analyzed by Mischke et al. (2015) who concluded that the deposits formed in a wetland including shallow freshwater to slightly oligohaline ponds, streams and swamps. Sediment accumulation occurred during the second half of MIS 3 and was replaced by erosion in MIS 2. However, sediments of preMIS 3 age were not included in their study. In contrast, Davies (2005) studied a 31-m long core from the basin which included clay, sandy clays and gravel lenses beneath an 11-m thick aeolianalluvial sediment cover which was apparently formed in MIS 2 . The lower stratigraphic unit was not dated but clays at the base of the core were regarded as formed in a deep lacustrine environment, overlain by multiple sequences of alluvial deposits, possibly formed during individual large flooding events. However, the inference of wetlands in MIS 3 shows that slightly wetter conditions in the Late Pleistocene probably led to a remarkable landscape change at this southeastern, even more arid location in Jordan. 


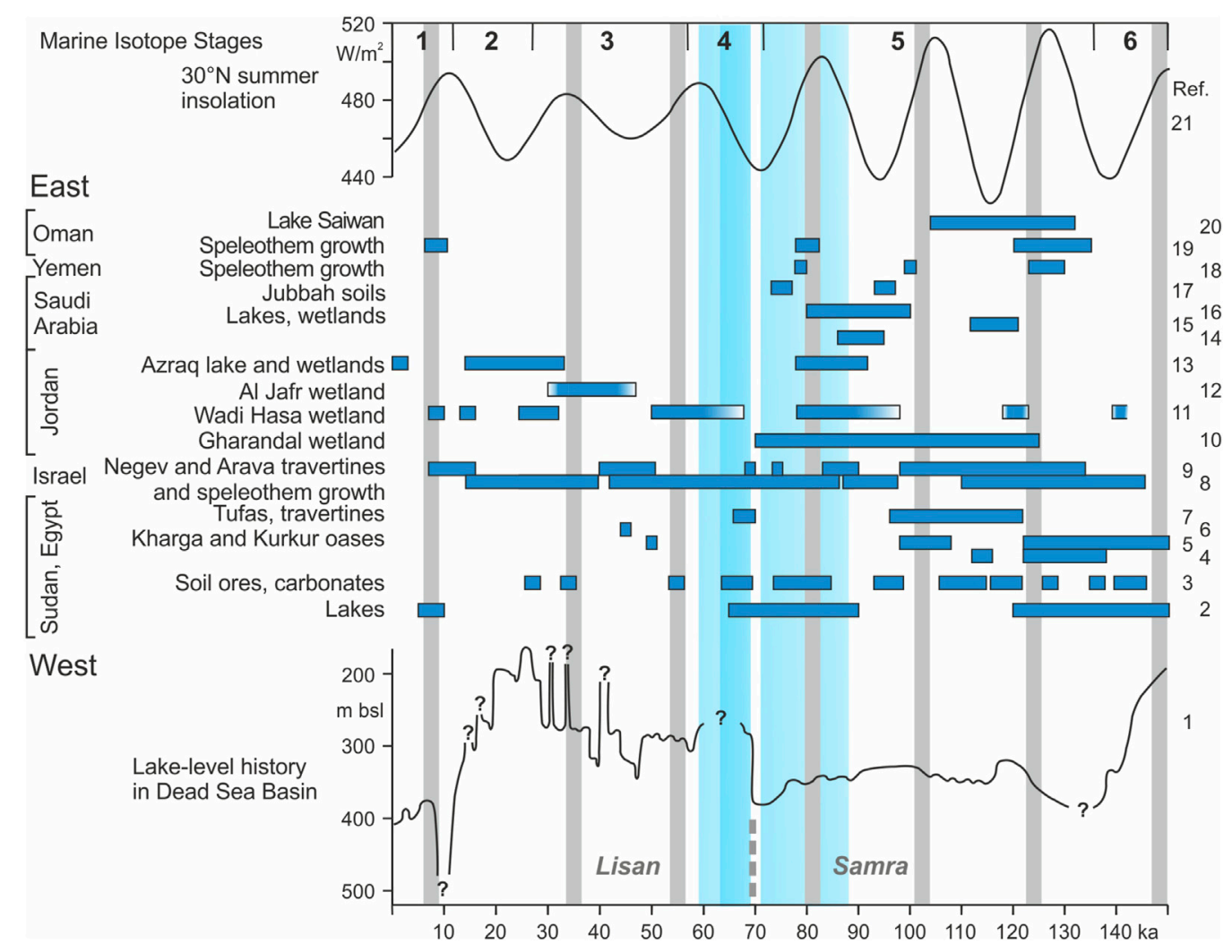

FIGURE 11 | Late Pleistocene and Holocene lake-level history in the Dead Sea Basin, and records of wetter climate conditions (horizontal blue bars) in the region in comparison to the dated artefact-bearing bed at Jurf ed Darawish marked by vertical blue bars. Vertical grey bars indicate sapropels in the eastern Mediterranean Sea north of the Nile delta (Zhao et al., 2011). Broken grey line marks the Samra-Lisan lakes' change. References of other climate records are 1 Bartov et al. (2002), Bartov et al. (2003), Bartov et al. (2007), Waldmann et al. (2007); 2 Szabo et al. (1995); 3 Osmond and Dabous (2004); 4 Smith et al. (2007); 5 Smith et al. (2004); 6 Sultan et al. (1997); 7 Crombie et al. (1997); 8 Vaks et al. (2006), Vaks et al. (2007); 9 Schwarcz et al. (1979), Livnat and Kronfeld (1985), Enmar (1999), Waldmann et al. (2010); 10 Al-Saqarat et al. (2021); 11 Winer (2010); 12 Mischke et al. (2015); 13 Cordova et al. (2013); 14 Groucutt et al. (2018); 15 Stewart et al. (2020b); 16 Groucutt et al. (2015); 17 Petraglia et al. (2011); 18 Fleitmann et al. (2011); 19 Fleitmann et al. (2003); 20 Rosenberg et al. (2012); 21 Berger and Loutre (1991).

Sediments incised by Wadi Gharandal, a tributary of Wadi Araba ca. $90 \mathrm{~km}$ southwest of Jurf ed Darawish, were regarded as formed in the Pleistocene Lake Lisan by Bender (1968). The recent reassessment by Al-Saqarat et al. (2021) revealed that the sediments represent a wetland sequence accumulated in the wadi between ca. $125-70 \mathrm{ka}$. A minimum age of ca. $75 \mathrm{ka}$ was determined for two Levallois flakes which are possibly evidence for the contemporary presence of humans at Jurf ed Darawish and Gharandal. Additional evidence for the presence of springs and densely vegetated areas including reeds, comes from the northern Wadi Arava/Araba ca. $70 \mathrm{~km}$ north of Gharandal, where travertines with determined ages of ca. 130, 90 and $70 \mathrm{ka}$ were apparently formed at the same time as the wetlands in Wadi Gharandal and at Jurf ed Darawish (Livnat and Kronfeld, 1985; Waldmann et al., 2010).

Dating of ostrich shells from archaeological excavations of two rock shelters (Tor Sabiha and Tor Faraj; Figure 1) ca. $90 \mathrm{~km}$ to the south of Jurf ed Darawish yielded ages of ca. $70 \mathrm{ka}$ (Henry and Miller, 1992). Together with 60-50 ka old animal teeth from the excavation of Fara II at the northern margin of the Negev Desert, Henry and Miller (1998, p. 45) already suggested more than two decades ago "an uninterrupted cultural development stretching from ca. $80-45 \mathrm{~K}$ bp for the arid zone of the southern Levant" (Schwarcz and Rink, 1998; Goder-Goldberger et al., 2020; Figure 1). Our new data from Jurf ed Darawish show that human occupation in the southern Levant was possible not only at few locations characterized by locally specific, very favourable hydrological conditions during the late MIS 5 and in MIS 4. Instead, lowered temperatures and reduced evaporation led to a higher moisture availability and abundant surficially accessible water resources for game and humans.

A wetter climate at ca. $70 \mathrm{ka}$ is also inferred from the coincidence of the reconstructed summer insolation minimum and the dramatic lake-level rise by $70-80 \mathrm{~m}$ in the Dead Sea Basin at the Samra-Lisan lakes transition (Berger and Loutre, 1991; Waldmann et al., 2007; Figure 11). It is still debated whether precipitation increased mainly in the northernmost catchment of Lake Lisan (i.e., Mount Hermon, the Golan Heights and Upper Galilee) or whether also higher precipitation in its central parts such as the Judean Mountains contributed to the initial rise in lake level and subsequently maintained high level (Waldmann et al., 2007; Enzel et al., 2008). The study at Jurf ed Darawish 
shows that regions as remote from the seas as precipitationsource areas such as the Jordanian Plateau apparently received higher precipitation than today and likely contributed to high levels of Lake Lisan in MIS 4 and 3.

Further south in the Negev Desert, wetter conditions were inferred from speleothem growth between 84 and $13 \mathrm{ka}$ and from the formation of loess and calcic soils, and thus, the presence of a relatively dense vegetation cover, which started ca. $80-75 \mathrm{ka}$ and mainly prevailed during MIS 4-2 (Vaks et al., 2006; Enzel et al., 2008; Crouvi et al., 2009). Travertines formed in hydrologically favourable conditions of Nahal (i.e., stream) Aqev in the northcentral Negev Highlands in the Middle and Late Pleistocene but they are not necessarily evidence of wetter climate conditions since travertine is formed in specific locations in the valley even today. However, Schwarcz et al. (1979) determined ages of 80 and $46 \mathrm{ka}$ for two different artefact-bearing travertine deposits which show that humans inhabited the region at the same time as Jurf ed Darawish.

Wetter conditions in the Late Pleistocene in more distant regions such as the Western Desert in Egypt and Sudan were recorded as a result of studies of lake sediments, travertine and ore deposits, and soil carbonates. For example, Szabo et al. (1995) inferred pluvial conditions and enhanced monsoonal circulation between 90 and $65 \mathrm{ka}$ based on the identification and dating of lake sediments (Figure 11). Osmond and Dabous (2004) dated carbonate and oxidized iron deposits, and phosphorite ores as evidence of enhanced groundwater circulation in the Egyptian Sahara. They determined an especially high number of age data between 90 and $70 \mathrm{ka}$. Dating of travertines in Egypt's Western Desert yielded Middle Pleistocene and younger ages of ca. 150-122, 116-198, 68 and $50 \mathrm{ka}$ (Crombie et al., 1997; Smith et al., 2004, 2007; Figure 11).

On the Arabian Peninsula, lakes and wetlands existed between 132 to 104 and 100 to $80 \mathrm{ka}$ (Rosenberg et al., 2012; Groucutt et al., 2015, 2018; Stewart et al., 2020b; Figure 11). Soil formation was recorded in Saudi Arabia's hyperarid Nefud Desert ca. 95 and $75 \mathrm{ka}$ (Petraglia et al., 2011). Periods of rapid speleothem growth in the Yemeni Highlands and Oman Mountains as indicators of wetter climate conditions occurred ca. 135-120, 100 and 82-78 ka (Fleitmann et al., 2003, 2011; Figure 11). Thus, the presence of humans on the central Jordanian Plateau in the Late Pleistocene falls apparently into a period of generally wetter conditions in the southern Levant, the eastern Sahara and the Arabian Peninsula.

Sediment accumulation at Jurf ed Darawish during most of the late Pleistocene was replaced by an erosional setting sometime after $30 \mathrm{ka}$ (Figure 3). As a result, the sequence of the accumulated Pleistocene sediments was removed in the Wadi El Jurf, and the Maastrichtian bedrock became exposed. We assume that similarly dry conditions as occur today with very sparse desert vegetation led to the establishment of the erosional setting. In the Negev Highlands, erosion started after a long period of dust aggradation at ca. $24 \mathrm{ka}$ and incision culminated at the Pleistocene-Holocene transition (Faershtein et al., 2016). In the $\mathrm{Al}$ Jafr Basin, wetland deposits were formed in the second half of MIS 3, followed by drier conditions in MIS 2 (Davies 2005; Mischke et al., 2015). The more intensively investigated Lake Lisan experienced a stepwise lake-level decline after the highest level was reached between 27 and 24 ka when the lake was merged with the Sea of Galilee (Hazan et al., 2005; Bartov et al., 2007; Waldmann et al., 2007). However, the most dramatic lake-level fall occurred at ca. $14 \mathrm{ka}$ (Torfstein et al., 2013). Thus, we may speculate that sediment accumulation continued in the Jurf ed Darawish region until ca. $24 \mathrm{ka}$, followed by erosion which probably became most intensive before and during the Pleistocene-Holocene transition.

\section{CONCLUSION}

Evidence from Jurf ed Darawish suggests that an aggradational setting dominated in the present hyperarid region since at least the middle of MIS 5 and during MIS 4 and 3. Dust deposition and loess formation must have resulted from a significantly denser vegetation cover. An in-stream wetland existed at Jurf ed Darawish during MIS 5-4, and was replaced by a vegetated alluvial plain in MIS 3. The accumulation of reworked, secondary fluvial loess continued at Jurf ed Darawish until at least 30 ka before erosion started to prevail sometime afterwards. The new data from Jurf ed Darawish and published information from other locations in the southern Levant show that streams and in-stream and spring-fed wetlands occurred on the Jordanian Plateau, in Wadi Arava/Araba and in the Negev in the Late Pleistocene (Schwarcz et al., 1979; Waldmann et al., 2010; Winer, 2010; Al-Saqarat et al., 2021).

The distribution of artefacts in sediments which accumulated at Jurf ed Darawish between ca. 85 to $65 \mathrm{ka}$ is evidence for a relatively long presence of humans in the region. Artefact-bearing sediments at Gharandal with an age of at least $75 \mathrm{ka}, \mathrm{ca} .70$-ka old ostrich shells from excavations at Tor Sabiha and Tor Faraj in southwestern Jordan, 80-ka old artefacts in travertine deposits in the Negev Desert, 60-50-ka old animal teeth from the excavation at Fara II at its northern margin, and the 85-ka old human remains from Al Wusta in the Nefud Desert show that humans were present in a wide region of the southern Levant and Arabian Peninsula in the late MIS 5 and during MIS 4 (Figure 1). Thus, favourable conditions in the middle of the Late Pleistocene had turned at least significant portions of today's desert barrier of the southern Levant and the Arabian Peninsula into a bridge between climatically more favourable regions in the south and north. The described evidence for the presence of humans in the southern Levant and Arabian Peninsula between ca. 85 to 60 ka fills the gap between two distinct movements identified within the Out-ofAfrica 2 model between ca. 130 to 80 and after $50 \mathrm{ka}$ (Garcea, 2012). However, our study leaves open whether the embedded artefacts in the sediments of Jurf ed Darawish represent repeated visits or an uninterrupted presence of humans in the region. Detailed archaeological investigations of the sedimentary sequences of Jurf ed Darawish are required to address this question.

According to the temperature record of the Greenland ice cap, the period between 85 and $60 \mathrm{ka}$ includes an initial long-term cooling and later on one of the coldest periods of the entire Late Pleistocene between 70 and 60 ka which was only interrupted by a single short-term warming at ca. $65 \mathrm{ka}$ (Kindler et al., 2014). This 
latter period represents the largest increase of global ice sheets in the Late Pleistocene (Batchelor et al., 2019). Thus, lower temperatures, rapid sea-level fall and resulting re-arrangements of the atmospheric circulation were apparently key for the reconstructed landscape change in the southern Levant.

Generally wetter conditions represented by reworked, secondary fluvial loess at Jurf ed Darawish during the Late Pleistocene possibly resulted from 1) the lowered temperatures and reduced evaporation effects which caused an increase in available moisture, and 2) more efficient eastern Mediterranean cyclones which also reached relatively far inland. These eastern Mediterranean cyclones, typically called Cyprus Lows, could have transported more moisture to the southern Levant as a result of a generally more southern location of its pathways and/or a higher frequency of arriving lows (Saaroni et al., 2010). Cyprus Lows reach the eastern Mediterranean coast today mostly in the northern Levant, but the glaciations of Scandinavia and the Alps, and extended snow covers at northern and middle latitudes and related katabatic winds probably forced the westerlies circulation of the Mediterranean to a more southern position in comparison to today. Minor temperature reductions in subtropical regions in the Pleistocene probably resulted in a weaker influence of the descending branch of the Hadley cell, also contributing to a more efficient transport of moist air from the Mediterranean Sea to the southern Levant. Enzel et al. (2008) proposed that eastern Mediterranean lows were funnelled by the ice and snow cover in Europe and Turkey, the lower sea level and the Sahara during the Late Pleistocene over the sea and directed to the east. In addition, climate model simulations predict a poleward shift of North Atlantic storm tracks, decrease of winter rain in the Middle East and weakening of Mediterranean storm tracks in a warmer future (Black et al., 2010). Accordingly, an equatorward shift of North Atlantic storm tracks, increase of winter rain in the Middle East and strengthening of Mediterranean storm tracks are expected for globally cooler conditions.

Further downstream, sediments similar to those at Jurf ed Darawish and previously described as lake sediments were reassessed as in-stream wetland deposits by Winer (2010). Similar sediments exist also $6 \mathrm{~km}$ upstream of Jurf ed Darawish in Wadi Juheira, where they were assessed as lake deposits (Neeley, 2004). A sedimentological and palaeontological reassessment could show whether these sediments were formed in a lake or similar to those at Jurf ed Darawish and Wadi Hasa in an in-stream wetland setting.

Wetter climate conditions and presence of humans during the late MIS 5 and during MIS 4 were inferred in a wide region from the Negev Desert in the west to the Nefud Desert in the east. A missing piece in the emerging puzzle of contemporaneously accumulated sediments are potentially the clays and sandy clays under an 11-m thick cover of wetland, alluvial and aeolian deposits in the Al Jafr Basin. Sediments between 31 and $11 \mathrm{~m}$ depth were partly regarded as lake deposits by Davies (2005) who conducted loss-on-ignition and element geochemistry analyses. Dating of sediments above provided ages of 24 and $16 \mathrm{ka}$ but the age of the finer-grained sediments below is still not determined. New analyses of sediments from the Al Jafr and other endorheic basins further south and east have the potential to shed more light on the environmental and landscape change in the southern Levant during the Late Pleistocene.

\section{DATA AVAILABILITY STATEMENT}

The raw data supporting the conclusion of this article will be made available by the authors, without undue reservation.

\section{AUTHOR CONTRIBUTIONS}

SM and HG designed the study; SM, GF, HG, PB, MR, and JK conducted fieldwork; GF, NP, and ZL conducted OSL dating; MR conducted grain-size analysis; JK performed sediment geochemistry analysis; SM and $\mathrm{PB}$ conducted microfossil analysis; SM wrote the manuscript draft and all contributed to the revision of the manuscript.

\section{FUNDING}

This work was funded by the Deutsche Forschungsgemeinschaft (Grant Mi 730/18-1 to SM).

\section{ACKNOWLEDGMENTS}

Logistical support of fieldwork of SM, MR, PB, and JK was kindly provided by Bety S. Al-Saqarat (University of Jordan, Amman) and Linah N. Ababneh (Cornell University, Ithaca). Bernhard Diekmann and Ute Bastian (Alfred Wegener Institute for Polar and Marine Research, Potsdam) provided lab access and supported the grain-size analysis, and Stephan Opitz (University of Cologne) and Karsten Adler (GFZ German Research Centre for Geosciences Potsdam) helped with analyses of grain-size data. We thank Antje Musiol who ran the TOC and TC analyses at the Institute of Geosciences at Potsdam University. The photo of Figure 10 was kindly contributed by Wolfgang Streicher. Very constructive reviews were provided by JP and JL.

\section{SUPPLEMENTARY MATERIAL}

The Supplementary Material for this article can be found online at: https:/www.frontiersin.org/articles/10.3389/feart.2021.722435/ full\#supplementary-material 


\section{REFERENCES}

Aitken, M. J. (1985). Thermoluminescence Dating. London: Academic Press.

Al-Saqarat, B. S., Abbas, M., Lai, Z., Gong, S., Alkuisi, M. M., Abu Hamad, A. M. B., et al. (2021). A Wetland Oasis at Wadi Gharandal Spanning 125-70 Ka on the Human Migration Trail in Southern Jordan. Quat. Res. 100, 154-169. doi:10.1017/qua.2020.82

Amit, R., Enzel, Y., and Crouvi, O. (2020). Quaternary Influx of Proximal CoarseGrained Dust Altered Circum-Mediterranean Soil Productivity and Impacted Early Human Culture. Geology 49, 61-65. doi:10.1130/g47708.1

Bandel, K., and Salameh, E. M. (2013). Geologic Development of Jordan - Evolution of its Rocks and Life. Deposit No. 690/3/2013 of the. Amman: National Library.

Bartov, Y., Enzel, Y., Porat, N., and Stein, M. (2007). Evolution of the Late Pleistocene Holocene Dead Sea Basin from Sequence Statigraphy of Fan Deltas and Lake-Level Reconstruction. J. Sediment. Res. 77, 680-692. doi:10.2110/jsr.2007.070

Bartov, Y., Goldstein, S. L., Stein, M., and Enzel, Y. (2003). Catastrophic Arid Episodes in the Eastern Mediterranean Linked with the North Atlantic Heinrich Events. Geol 31, 439-442. doi:10.1130/0091-7613(2003)031<0439:caeite>2.0.co;2

Bartov, Y., Stein, M., Enzel, Y., Agnon, A., and Reches, Z. e. (2002). Lake Levels and Sequence Stratigraphy of Lake Lisan, the Late Pleistocene Precursor of the Dead Sea. Quat. Res. 57, 9-21. doi:10.1006/qres.2001.2284

Batchelor, C. L., Margold, M., Krapp, M., Murton, D. K., Dalton, A. S., Gibbard, P. L., et al. (2019). The Configuration of Northern Hemisphere Ice Sheets through the Quaternary. Nat. Commun. 10, 3713. doi:10.1038/s41467-019-11601-2

Ben David, R. (2003). Changes in Desert Margin Environments during the Climate Changes of the Late thesosQuaternary: Interaction between Drainage Systems and the Accumulation of Dust (Loess) and the Invasion of Dunes at the North-West Negev Desert. Jerusalem: Ph.D. Dissertation at The Hebrew University of Jerusalem, 170. (in Hebrew with Engl. abstr.).

Benaafi, M., and Abdullatif, O. (2015). Sedimentological, Mineralogical, and Geochemical Characterization of Sand Dunes in Saudi Arabia. Arab J. Geosci. 8, 11073-11092. doi:10.1007/s12517-015-1970-9

Bender, F. (1968). Geologie von Jordanien. Stuttgart: Gebrüder Borntraeger, 230.

Berger, A., and Loutre, M. F. (1991). Insolation Values for the Climate of the Last 10 Million Years. Quat. Sci. Rev. 10, 297-317. doi:10.1016/0277-3791(91) 90033-q

Black, E., Brayshaw, D. J., and Rambeau, C. M. C. (2010). Past, Present and Future Precipitation in the Middle East: Insights from Models and Observations. Phil. Trans. R. Soc. A. 368, 5173-5184. doi:10.1098/rsta.2010.0199

Catlett, G. A., Rech, J. A., Pigati, J. S., and Al Kuisi, M. (2013). Paleoclimatic Implications of Pluvial Deposits in Mudawwara, Jordan. Geol. Soc. Am. Abstr. Programs 45, 680.

Clark, G. A. (1984). The Negev Model for Paleoclimatic Change and Human Adaptation in the Levant and its Relevance for the Paleolithic of the Wadi El Hasa (West-Central Jordan). Annu. Department Antiquities Jordan 28, 225-248.

Cordova, C. E., Foley, C., Nowell, A., and Bisson, M. (2005). Landforms, Sediments, Soil Development, and Prehistoric Site Settings on the Madaba-Dhiban Plateau, Jordan. Geoarchaeology 20, 29-56. doi:10.1002/gea.20036

Cordova, C. E., Nowell, A., Bisson, M., Ames, C. J. H., Pokines, J., Chang, M., et al. (2013). Interglacial and Glacial Desert Refugia and the Middle Paleolithic of the Azraq Oasis, Jordan. Quat. Int. 300, 94-110. doi:10.1016/j.quaint.2012.09.019

Crombie, M. K., Arvidson, R. E., Sturchio, N. C., El Alfy, Z., and Zeid, K. A. (1997). Age and Isotopic Constraints on Pleistocene Pluvial Episodes in the Western Desert, Egypt. Palaeogeogr. Palaeoclimatol. Palaeoecol. 130, 337-355. doi:10.1016/s0031-0182(96)00134-4

Crouvi, O., Amit, R., Enzel, Y., Porat, N., and Sandler, A. (2008). Sand Dunes as a Major Proximal Dust Source for Late Pleistocene Loess in the Negev Desert, Israel. Quat. Res. 70, 275-282. doi:10.1016/j.yqres.2008.04.011

Crouvi, O., Amit, R., Porat, N., Gillespie, A. R., McDonald, E. V., and Enzel, Y. (2009). Significance of Primary Hilltop Loess in Reconstructing Dust Chronology, Accretion Rates, and Sources: An Example from the Negev Desert, Israel. J. Geophys. Res. 114, F02017. doi:10.1029/2008jf001083

Davies, C. P. (2005). Quaternary Paleoenvironments and Potential for Human Exploitation of the Jordan Plateau Desert interior. Geoarchaeology: Int. J. 20, 381-400. doi:10.1002/gea.20055
Enmar, L. (1999). The Travertines in the Northern and Central Arava: Stratigraphy, Petrology and Geochemistry. Geol. Surv. Isr. Rep. 1/99, 111.

Enzel, Y., Amit, R., Dayan, U., Crouvi, O., Kahana, R., Ziv, B., et al. (2008). The Climatic and Physiographic Controls of the Eastern Mediterranean over the Late Pleistocene Climates in the Southern Levant and its Neighboring Deserts. Glob. Planet. Change 60, 165-192. doi:10.1016/j.gloplacha.2007.02.003

Enzel, Y., Kushnir, Y., and Quade, J. (2015). The Middle Holocene Climatic Records from Arabia: Reassessing Lacustrine Environments, Shift of ITCZ in Arabian Sea, and Impacts of the Southwest Indian and African Monsoons. Glob. Planet. Change 129, 69-91. doi:10.1016/j.gloplacha.2015.03.004

Faershtein, G., Porat, N., Avni, Y., and Matmon, A. (2016). Aggradation-incision Transition in Arid Environments at the End of the Pleistocene: an Example from the Negev Highlands, Southern Israel. Geomorphology 253, 289-304. doi:10.1016/j.geomorph.2015.10.017

Faershtein, G., Porat, N., and Matmon, A. (2020). Extended-Range Luminescence Dating of Quartz and Alkali Feldspar from Aeolian Sediments in the Eastern Mediterranean. Geochronology 2, 101-118. doi:10.5194/gchron-2-101-2020

Findlater, G. M. (2003). Imperial Control in Roman and Byzantine Arabia: A Landscape Interpretation of Archaeological Evidence in Southern Jordan. Edinburgh: Ph.D. Dissertation at The University of Edinburgh, 484.

Fleitmann, D., Burns, S. J., Neff, U., Mangini, A., and Matter, A. (2003). Changing Moisture Sources over the Last 330,000 Years in Northern Oman from FluidInclusion Evidence in Speleothems. Quat. Res. 60, 223-232. doi:10.1016/s00335894(03)00086-3

Fleitmann, D., Burns, S. J., Pekala, M., Mangini, A., Al-Subbary, A., Al-Aowah, M., et al. (2011). Holocene and Pleistocene Pluvial Periods in Yemen, Southern Arabia. Quat. Sci. Rev. 30, 783-787. doi:10.1016/j.quascirev.2011.01.004

Fuhrmann, R. (2012). Atlas quartärer und rezenter Ostrakoden Mitteldeutschlands. Altenburger Naturwissenschaftliche Forschungen 15, 1-320.

Galbraith, R. F., and Roberts, R. G. (2012). Statistical Aspects of Equivalent Dose and Error Calculation and Display in OSL Dating: an Overview and Some Recommendations. Quat. Geochronol. 11, 1-27. doi:10.1016/ j.quageo.2012.04.020

Garcea, E. A. A. (2012). Successes and Failures of Human Dispersals from North Africa. Quat. Int. 270, 119-128. doi:10.1016/i.quaint.2011.06.034

Ginat, H., Opitz, S., Ababneh, L., Faershtein, G., Lazar, M., Porat, N., et al. (2018). Pliocene-Pleistocene Waterbodies and Associated Deposits in Southern Israel and Southern Jordan. J. Arid Environments 148, 14-33. doi:10.1016/ j.jaridenv.2017.09.007

Goder-Goldberger, M., Crouvi, O., Caracuta, V., Kolska Horwitz, L., Neumann, F. H., Porat, N., et al. (2020). The Middle to Upper Paleolithic Transition in the Southern Levant: New Insights from the Late Middle Paleolithic Site of Far'ah II, Israel. Quat. Sci. Rev. 237, 106304. doi:10.1016/j.quascirev.2020.106304

Groucutt, H. S., Grün, R., Zalmout, I. A. S., Drake, N. A., Armitage, S. J., Candy, I., et al. (2018). Homo sapiens in Arabia by 85,000 Years Ago. Nat. Ecol. Evol. 2, 800-809. doi:10.1038/s41559-018-0518-2

Groucutt, H. S., White, T. S., Clark-Balzan, L., Parton, A., Crassard, R., Shipton, C., et al. (2015). Human Occupation of the Arabian Empty Quarter during MIS 5: Evidence from Mundafan Al-Buhayrah, Saudi Arabia. Quat. Sci. Rev. 119, 116-135. doi:10.1016/j.quascirev.2015.04.020

Hazan, N., Stein, M., Agnon, A., Marco, S., Nadel, D., Negendank, J. F. W., et al. (2005). The Late Quaternary Limnological History of Lake Kinneret (Sea of Galilee), Israel. Quat. Res. 63, 60-77. doi:10.1016/j.yqres.2004.09.004

Henry, D. O., and Miller, G. H. (1992). The Implications of Amino Acid Racemization Dates of Levantine Mousterian Deposits in Southern Jordan. paleo 18, 45-52. doi:10.3406/paleo.1992.4572

Huckriede, R., and Wiesemann, G. (1968). Der jungpleistozäne Pluvial-See von ElJafr und weitere Daten zum Quartär Jordaniens. Geologica et Paleontologica 2, 73-95.

Hunt, C. O., Elrishi, H. A., Gilbertson, D. D., Grattan, J., Mclaren, S., Pyatt, F. B., et al. (2004). Early-Holocene Environments in the Wadi Faynan, Jordan. The Holocene 14, 921-930. doi:10.1191/0959-683604hl769rp

Janz, H. (1994). Zur Bedeutung des Schalenmerkmals ,Marginalrippen' der Gattung Ilyocypris (Ostracoda, Crustacea). Stuttgarter Beiträge zur Naturkunde Serie B 206, 1-19.

Kindler, P., Guillevic, M., Baumgartner, M., Schwander, J., Landais, A., and Leuenberger, M. (2014). Temperature Reconstruction from 10 to $120 \mathrm{Kyr}$ 
B2k from the NGRIP Ice Core. Clim. Past 10, 887-902. doi:10.5194/cp-10-8872014

Lai, Z.-P., and Wintle, A. G. (2006). Locating the Boundary between the Pleistocene and the Holocene in Chinese Loess Using Luminescence. The Holocene 16, 893-899. doi:10.1191/0959683606hol980rr

Lai, Z., and Brückner, H. (2008). Effects of Feldspar Contamination on Equivalent Dose and the Shape of Growth Curve for OSL of Silt-Sized Quartz Extracted from Chinese Loess. Geochronometria 30, 49-53. doi:10.2478/v10003-0080010-0

Lai, Z. P., Zöller, L., Fuchs, M., and Brückner, H. (2008). Alpha Efficiency Determination for OSL of Quartz Extracted from Chinese Loess. Radiat. Measurements 43, 767-770. doi:10.1016/j.radmeas.2008.01.022

Lai, Z. (2006). Testing the Use of an OSL Standardised Growth Curve (SGC) for Determination on Quartz from the Chinese Loess Plateau. Radiat. Measurements 41, 9-16. doi:10.1016/j.radmeas.2005.06.031

Lindly, J., and Clark, G. (1987). A Preliminary Lithic Analysis of the Mousterian Site of 'Ain Difla (WHS Site 634) in the Wadi Ali, West-Central Jordan. Proc. Prehist. Soc. 53, 279-292. doi:10.1017/s0079497x00006228

Livnat, A., and Kronfeld, J. (1985). Paleoclimatic Implications of U-Series Dates for lake Sediments and Travertines in the Arava Rift Valley, Israel. Quat. Res. 24, 164-172. doi:10.1016/0033-5894(85)90003-1

Lucke, B., Kemnitz, H., Bäumler, R., and Schmidt, M. (2013). Red Mediterranean Soils in Jordan: New Insights in Their Origin, Genesis, and Role as Environmental Archives. Catena 112, 4-24.

MacDonald, B., Bradshaw, A., Herr, L., Neeley, M., and Quaintance, S. (2000). The Tafila-Busayra Archaeological Survey: Phase 1 (1999). Annu. Department Antiquities Jordan 44, 507-522.

MacDonald, B., Herr, L., Neeley, M. P., Quaintance, S., and Bradshaw, A. (2001). The Tafila-Busayra Archaeological Survey: Phase 2 (2000). Annu. Department Antiquities Jordan 45, 395-411.

Meisch, C. (2000). Freshwater Ostracoda of Western and Central Europe. Heidelberg: Spektrum.

Mischke, S., Opitz, S., Kalbe, J., Ginat, H., and Al-Saqarat, B. (2015). Palaeoenvironmental Inferences from Late Quaternary Sediments of the Al Jafr Basin, Jordan. Quat. Int. 382, 154-167. doi:10.1016/j.quaint.2014.12.041

Moumani, K., Alexander, J., and Bateman, M. D. (2003). Sedimentology of the Late Quaternary Wadi Hasa Marl Formation of Central Jordan: a Record of Climate Variability. Palaeogeogr. Palaeoclimatol. Palaeoecol. 191, 221-242. doi:10.1016/ s0031-0182(02)00715-0

Moumani, K. A. (1996). The Geology of Jurf Ed Darawish, Map Sheet (3151 II), 1:50 000 National Mapping Project, Natural Resources Authority. Amman: Geological Directorate, Mapping Division.

Neeley, M. (2004). "Late Epipaleolithic Settlement in the Wadi Juheira, Westcentral Jordan," in The Last Hunter-Gatherer Societies in the Near East. Editor C. Delage (Oxford: John and Erica Hedges), 39-54.

Osmond, J. K., and Dabous, A. A. (2004). Timing and Intensity of Groundwater Movement during Egyptian Sahara Pluvial Periods by U-Series Analysis of Secondary U in Ores and Carbonates. Quat. Res. 61, 85-94. doi:10.1016/ j.yqres.2003.09.004

Palmer, C. (2013). "Biogeography," in Atlas of Jordan; History, Territories and Society. Editor M. Ababsa (Beyrouth: Presses de l'Ifpo), 77-87. doi:10.4000/ books.ifpo. 4871

Petit-Maire, N., Carbonel, P., Reyss, J. L., Sanlaville, P., Abed, A., Bourrouilh, R., et al. (2010). A Vast Eemian Palaeolake in Southern Jordan $\left(29^{\circ} \mathrm{N}\right)$. Glob. Planet. Change 72, 368-373. doi:10.1016/j.gloplacha.2010.01.012

Petraglia, M. D., Alsharekh, A. M., Crassard, R., Drake, N. A., Groucutt, H., Parker, A. G., et al. (2011). Middle Paleolithic Occupation on a Marine Isotope Stage 5 Lakeshore in the Nefud Desert, Saudi Arabia. Quat. Sci. Rev. 30, 1555-1559. doi:10.1016/j.quascirev.2011.04.006

Pigati, J. S., Rech, J. A., Quade, J., and Bright, J. (2014). Desert Wetlands in the Geologic Record. Earth-Science Rev. 132, 67-81. doi:10.1016/j.earscirev.2014.02.001

Porat, N., Rosen, S. A., Boaretto, E., and Avni, Y. (2006). Dating the Ramat Saharonim Late Neolithic Desert Cult Site. J. Archaeological Sci. 33, 1341-1355. doi:10.1016/j.jas.2006.01.008

Prescott, J. R., and Hutton, J. T. (1994). Cosmic Ray Contributions to Dose Rates for Luminescence and ESR Dating: Large Depths and Long-Term Time Variations. Radiat. Measurements 23, 497-500. doi:10.1016/1350-4487(94) 90086-8
Quade, J., Forester, R. M., Pratt, W. L., and Carter, C. (1998). Black Mats, SpringFed Streams, and Late-Glacial-Age Recharge in the Southern Great Basin. Quat. Res. 49, 129-148. doi:10.1006/qres.1997.1959

Rech, J. A., Ginat, H., Catlett, G. A., Mischke, S., Winer Tully, E., and Pigati, J. S. (2017). "Pliocene-Pleistocene Water Bodies and Associated Deposits in Southern Israel and Southern Jordan," in Quaternary of the Levant: Environments, Climate Change, and Humans. Editors Y. Enzel and O. BarYosef (Cambridge University Press), 127-134.

Roberts, H. M., and Duller, G. A. T. (2004). Standardised Growth Curves for Optical Dating of Sediment Using Multiple-Grain Aliquots. Radiat. Measurements 38, 241-252. doi:10.1016/j.radmeas.2003.10.001

Röhl, M. (2015). Rekonstruktion pleistozäner Ablagerungsräume im südlichen Israel und Jordanien anhand von Korngrößendaten. Berlin: M.Sc. thesis at the Institute of Geological Sciences, Free University Berlin, 74. (in German with English abstract).

Rosenberg, T. M., Preusser, F., Blechschmidt, I., Fleitmann, D., Jagher, R., and Matter, A. (2012). Late Pleistocene Palaeolake in the interior of Oman: a Potential Key Area for the Dispersal of Anatomically Modern Humans Out-OfAfrica? J. Quat. Sci. 27, 13-16. doi:10.1002/jqs.1560

Saaroni, H., Halfon, N., Ziv, B., Alpert, P., and Kutiel, H. (2010). Links between the Rainfall Regime in Israel and Location and Intensity of Cyprus Lows. Int. J. Climatol. 30, 1014-1025. doi:10.1002/joc.1912

Saqqa, W., and Atallah, M. (2004). Characterization of the Aeolian Terrain Facies in Wadi Araba Desert, Southwestern Jordan. Geomorphology 62, 63-87. doi:10.1016/j.geomorph.2004.02.002

Schuldenrein, J., and Clark, G. A. (1994). Landscape and Prehistoric Chronology of West-central Jordan. Geoarchaeology 9, 31-55. doi:10.1002/gea.3340090103

Schuldenrein, J., and Clark, G. A. (2003). Prehistoric Landscapes and Settlement Geography along the Wadi Hasa, West-central Jordan. Part II: Towards a Model of Palaeoecological Settlement for the Wadi Hasa. Environ. Archaeology 8, 1-16. doi:10.1179/env.2003.8.1.1

Schwarcz, H. P., Blackwell, B., Goldberg, P., and Marks, A. E. (1979). Uranium Series Dating of Travertine from Archaeological Sites, Nahal Zin, Israel. Nature 277, 558-560. doi:10.1038/277558a0

Schwarcz, H. P., and Rink, J. W. (1998). "Progress in ESR and U-Series Chronology of the Levantine Paleolithic," in Neandertals and Modern Humans in Western Asia. Editors T. Akazawa, K. Aoki, and O. Bar-Yosef (New York: Plenum), 57-68.

Shea, J. J. (2003). The Middle Paleolithic of the East Mediterranean Levant. J. World Prehistory 17, 313-394. doi:10.1023/b:jowo.0000020194.01496.fe

Smith, J. R., Giegengack, R., Schwarcz, H. P., McDonald, M. M. A., Kleindienst, M. R., Hawkins, A. L., et al. (2004). A Reconstruction of Quaternary Pluvial Environments and Human Occupations Using Stratigraphy and Geochronology of Fossil-spring Tufas, Kharga Oasis, Egypt. Geoarchaeology: Int. J. 19, 1-34. doi:10.1002/gea.20004

Smith, J. R., Hawkins, A. L., Asmerom, Y., Polyak, V., and Giegengack, R. (2007). New Age Constraints on the Middle Stone Age Occupations of Kharga Oasis, Western Desert, Egypt. J. Hum. Evol. 52, 690-701. doi:10.1016/j.jhevol.2007.01.004

Stewart, M., Clark-Wilson, R., Breeze, P. S., Janulis, K., Candy, I., Armitage, S. J., et al. (2020b). Human Footprints Provide Snapshot of Last Interglacial Ecology in the Arabian interior. Sci. Adv. 6, eaba8940. doi:10.1126/sciadv.aba8940

Stewart, M., Louys, J., Breeze, P. S., Clark-Wilson, R., Drake, N. A., Scerri, E. M. L., et al. (2020a). A Taxonomic and Taphonomic Study of Pleistocene Fossil Deposits from the Western Nefud Desert, Saudi Arabia. Quat. Res. 95, 1-22. doi:10.1017/qua.2020.6

Suleiman, A., and Al-Bakri, J. (2011). "Estimating Actual Evapotranspiration Using ALARM and the Dimensionless Temperature," in Evapotranspiration. Editor L. Labedzki. doi:10.5772/13918IntechOpen

Sultan, M., Sturchio, N., Hassan, F. A., Hamdan, M. A. R., Mahmood, A. M., Alfy, Z. E., et al. (1997). Precipitation Source Inferred from Stable Isotopic Composition of Pleistocene Groundwater and Carbonate Deposits in the Western Desert of Egypt. Quat. Res. 48, 29-37. doi:10.1006/qres.1997.1907

Szabo, B. J., Haynes, C. V., and Maxwell, T. A. (1995). Ages of Quaternary Pluvial Episodes Determined by Uranium-Series and Radiocarbon Dating of Lacustrine Deposits of Eastern Sahara. Palaeogeogr. Palaeoclimatol. Palaeoecol. 113, 227-242. doi:10.1016/0031-0182(95)00052-n

Torfstein, A., Goldstein, S. L., Stein, M., and Enzel, Y. (2013). Impacts of Abrupt Climate Changes in the Levant from Last Glacial Dead Sea Levels. Quat. Sci. Rev. 69, 1-7. doi:10.1016/j.quascirev.2013.02.015 
Vaks, A., Bar-Matthews, M., Ayalon, A., Matthews, A., Frumkin, A., Dayan, U., et al. (2006). Paleoclimate and Location of the Border between Mediterranean Climate Region and the Saharo-Arabian Desert as Revealed by Speleothems from the Northern Negev Desert, Israel. Earth Planet. Sci. Lett. 249, 384-399. doi:10.1016/j.epsl.2006.07.009

Vaks, A., Bar-Matthews, M., Ayalon, A., Matthews, A., Halicz, L., and Frumkin, A. (2007). Desert Speleothems Reveal Climatic Window for African Exodus of Early Modern Humans. Geol 35, 831-834. doi:10.1130/g23794a.1

Vaks, A., Bar-Matthews, M., Ayalon, A., Schilman, B., Gilmour, M., Hawkesworth, C. J., et al. (2003). Paleoclimate Reconstruction Based on the Timing of Speleothem Growth and Oxygen and Carbon Isotope Composition in a Cave Located in the Rain Shadow in Israel. Quat. Res. 59, 182-193. doi:10.1016/s0033-5894(03)00013-9

Van Harten, D. (1979). Some New Shell Characters to Diagnose the Species of the Ilyocypris gibba-biplicata-bradyi Group and Their Ecological Significance. In 7th International Symposium on Ostracodes. Belgrade: Serbian Geological Society, 71-76.

Vita-Finzi, C. (1964). Observations on the Late Quaternary of Jordan. Palestine Exploration Q. 96, 19-33. doi:10.1179/peq.1964.96.1.19

Waldmann, N., Starinsky, A., and Stein, M. (2007). Primary Carbonates and Ca-Chloride Brines as Monitors of a Paleo-Hydrological Regime in the Dead Sea basin. Quat. Sci. Rev. 26, 2219-2228. doi:10.1016/ j.quascirev.2007.04.019

Waldmann, N., Torfstein, A., and Stein, M. (2010). Northward Intrusions of Lowand Mid-latitude Storms across the Saharo-Arabian belt during Past Interglacials. Geology 38, 567-570. doi:10.1130/g30654.1
Welter-Schultes, F. (2012). European Non-marine Molluscs, a Guide for Species Identification. Göttingen: Planet Poster Editions.

Winer, E. R. (2010). Interpretation and Climatic Significance of Late Quaternary valley-fill Deposits in Wadi Hasa, West-central Jordan. Oxford: M.Sc. thesis at Department of GeologyMiami University, 90.

Zhao, Y., Liu, Z., Colin, C., Paterne, M., Siani, G., Cheng, X., et al. (2011). Variations of the Nile Suspended Discharges during the Last 1.75Myr. Palaeogeogr. Palaeoclimatol. Palaeoecol. 311, 230-241. doi:10.1016/j.palaeo.2011.09.001

Conflict of Interest: The authors declare that the research was conducted in the absence of any commercial or financial relationships that could be construed as a potential conflict of interest.

Publisher's Note: All claims expressed in this article are solely those of the authors and do not necessarily represent those of their affiliated organizations, or those of the publisher, the editors and the reviewers. Any product that may be evaluated in this article, or claim that may be made by its manufacturer, is not guaranteed or endorsed by the publisher.

Copyright (C) 2021 Mischke, Lai, Faershtein, Porat, Röhl, Braun, Kalbe and Ginat This is an open-access article distributed under the terms of the Creative Commons Attribution License (CC BY). The use, distribution or reproduction in other forums is permitted, provided the original author(s) and the copyright owner(s) are credited and that the original publication in this journal is cited, in accordance with accepted academic practice. No use, distribution or reproduction is permitted which does not comply with these terms. 